\title{
Optimization of Chitosan Production from Iranian Medicinal Fungus Trametes- Versicolor by Taguchi Method and Evaluation of Antibacterial Properties
}

\author{
Negin Yasrebi ${ }^{1}$, Ashrafal Sadat Hatamian Zarmi ${ }^{2}$, Mohaddeseh Larypoor ${ }^{3}$
}

1. Department of Biology, Faculty of Bio Sciences, Tehran North Branch, Islamic Azad University, Tehran, Iran

2. Department of Life Sciences Engineering, Faculty of New Sciences and Technologies, University of Tehran, Tehran, Iran

3. Department of Biology, Faculty of Bio Sciences, Tehran North Branch, Islamic Azad University, Tehran, Iran

\subsection{9/ijmm.14.3.1}

\section{ABSTRACT}

Background: Chitosan is a natural polymer with special properties that are prepared and purified in the industry of crustaceans. In this study, Trametes versicolor fungus, which was obtained from the forests of northern Iran, was used due to its medicinal properties, and the extracted chitosan of this fungus was optimized and its antimicrobial properties were investigated.

Materials \& Methods: To increase chitosan, four influential $\mathrm{NaOH}$ parameters, time, temperature, and biomass to $\mathrm{NaOH}$ ratio were performed by the Taguchi method. Fourier Transformed Infrared Spectrometry (FTIR) was identified, and the antibacterial properties of the disc release method were investigated against Escherichia coli and Staphylococcus aureus bacteria and the bacterial non-growth halo by millimeters.

Results: The optimal conditions of the variables were: 5.94 Molar, 4 hours, and 40 minutes, 65.6 degrees Celsius, and 1:25 ratio, respectively. Under these conditions, the amount of chitosan produced was equal to $0.261 \mathrm{~g} / \mathrm{L}$ and the degree of deacetylation $78 \%$ was obtained. The antibacterial properties against $E$. coli gram-negative bacteria and $S$. aureus grampositive bacteria were found to be $12 \pm 1$ and $18 \pm 2$, respectively.

Conclusion: Evidence has shown that four parameters had a positive effect on more chitosan production and the $S$. aureus is more sensitive to the resulting chitosan.

Keywords: Trametes versicolor, Optimization, Chitosan, Taguchi, Disc diffusion

\begin{tabular}{|c|c|c|c|c|}
\hline \multicolumn{3}{|c|}{ Received: 2020/01/19; } & Accepted: 2020/06/08; & Published Online: 2020/06/18 \\
\hline \multicolumn{2}{|c|}{ Corresponding Information: } & \multicolumn{3}{|c|}{$\begin{array}{l}\text { Ashrafal Sadat Hatamian Zarmi, Assistant Professor, Department of Life Sciences Engineering, Faculty of New Sciences and } \\
\text { Technologies, University of Tehran, Tehran, Iran. Email: hatamian a@ut.ac.ir }\end{array}$} \\
\hline (C) $\underset{\mathrm{BY}}{(1)}(\mathrm{SC}$ & $\begin{array}{l}\text { Copyright }(\odot) 20 \\
\text { permits copy ar }\end{array}$ & $\begin{array}{l}\text { This is an original open } \\
\text { edistribution of the mat }\end{array}$ & $\begin{array}{l}\text { article distributed under the terms of } \\
\text { in noncommercial usages with prope }\end{array}$ & $\begin{array}{l}\text { eative Commons Attribution-noncommercial } 4.0 \text { International License which } \\
\text { ion. }\end{array}$ \\
\hline
\end{tabular}

Use your device to scan and read the article online

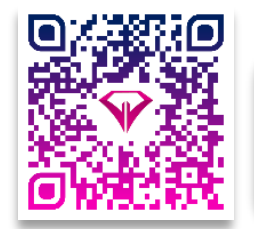

Yasrebi N, Hatamian Zarmi A S, Larypoor M. Optimization of Chitosan Production from Iranian Medicinal Fungus Trametes- Versicolor by Taguchi Method and Evaluation of Antibacterial Properties. Iran J Med Microbiol. 2020; 14 (3) :

Download citation: BibTeX | RIS | EndNote | Medlars | ProCite | Reference Manager | RefWorks Send citation to: $\otimes_{\text {Mendeley }} \mathbf{z}$ zotero $\mathbb{H}_{\text {RefWorks }}$ 


\section{Introduction}

Fungi are especially popular with researchers and the scientific community because of their unique properties. Species of wild mushrooms are also grown commercially in some communities. A distinctive feature of mushrooms is that they are an important source of biologically active compounds with medicinal value that have attracted the attention of many researchers around the world (1). These physiological medicinal properties include increased levels of immunity, regulation of heart rate, improving life-threatening diseases such as cancer, stroke and heart disease. They are also a valuable source of anti-inflammatory, antioxidant, anti-cancer, probiotic, antimicrobial and anti-diabetic compounds (2). Trametes versicolor, also known as Coriolus versicolor or Polypuras versicolor in East Asian countries, has been used in traditional medicine for medicinal purposes since ancient times and is currently used in modern medicine. The fungus is found all over the world, especially in the northern hemisphere. The fungus has various bioactive components, including polysaccharide peptide, krestin polysaccharide, which have been shown to have antitumor and anti-cancer properties. They also protect the animal liver from aflatoxins (3). Chitin is a polysaccharide derived from the fungus Trametes versicolor, which is considered as a commercial raw material for the production of chitosan and glucosamine. Chitosan becomes a flexible and soluble polymer through the deacetylation of chitin. Chitosan is a fiber-like and homopolymeric material, first introduced as a natural cationic flocculant for wastewater treatment in 1975 and it was used industrially (4). Chitosan is also found in some fungi and has gained much attention recently due to its special properties such as different chemical structure, non-toxicity, bio-compatibility with many organs and processing in various forms such as fibers, powders, membranes, gels, sponges and fiber $(5,6)$. These unique properties has led to its high potential to produce applied materials (7). In 2018, Mokhtari et al. Extracted and optimized chitin and chitosan of the Iranian fungus Ganoderma leucidum, for biopolymer production (9). Currently commercial chitosan is produced from marine resources, including crustaceans, but due to problems such as environmental pollution during the process of detoxification and the high cost of extraction from these resources as well as the contamination of waters with heavy metals due to the entry of petroleum products. Damage to vessels containing petroleum and ultimately contamination of hard-skinned creatures that are the main source of chitosan production have encouraged researchers with benefits such as lower costs for extraction, elimination of heavy metal contamination and mass production at the commercial level to extract this bioactive substance from Sources of fungi.
Therefore, in the present study, the production of chitin and chitosan from the native Iranian fungus Trametes Versicolor, isolated from the northern forests of Iran, was performed to extract chitosan from in vitro and extract chitin from biomass. Also, by studying the conditions of chitosan extraction, factors affecting the production of chitosan from this fungus were selected and optimized by the Taguchi method. Then chitosan FTIR analysis was performed and the chitosan deacetylation rate was calculated. Finally, the amount of chitosan antibacterial activity was calculated by disk diffusion method.

\section{Materials and Methods}

The materials used in this study include the Trametes Versicolor fungus isolated from the forests of Mazandaran in collaboration with Sari University of Agriculture. The identification of this fungus has been confirmed by mycologists based on morphology, kept at $4^{\circ} \mathrm{C}$. Medium molecular weight commercial chitosan, Potato dextrose agar culture, Potato dextrose broth medium of Merck Germany, sodium hydroxide, Merck Germany. Distilled water were used.

Mushroom Cultivation and Extraction of Chitin and Chitosan

Fungi were cultured in PDA (Potato dextrose agar) in vitro and kept in an incubator at $28^{\circ} \mathrm{C}$ for 7 days. Chitin and then chitosan were extracted from the biomass obtained (10). For chitin production, dried mycelium powder with 1:20 W / V ratio was mixed with $\mathrm{NaOH} 4$ $\mathrm{M}$ and placed in a water bath at $90^{\circ} \mathrm{C}$ for 3 hours. The remaining sediment is the same chitin by freeze-drying, dehydration and weight were measured (11). For extraction of chitosan, chitin was exposed to $45 \%$ concentrated sodium hydroxide for 4 hours at $90^{\circ} \mathrm{C}$ with a 1: $15 \mathrm{~W} / \mathrm{V}$ ratio. The remaining sediment was washed to neutral. Finally, chitosan was dehydrated by freeze drying method and weight was measured (12).

Optimization of Environmental Variables Affecting the Process of Chitosan Separation and Production from Trametes versicolor

According to the commonly used methods for designing experiments at different levels, the Taguchi method was chosen. To find the optimum conditions for further production of chitosan, some of the effective parameters in chitosan extraction such as temperature, process time, biomass to $\mathrm{NaOH}$ ratio and $\mathrm{NaOH}$ concentration were investigated. In this study, experiments were evaluated with 4 factors at three levels. The L9 array was used for this purpose.

Factors and levels are listed in Table 1. Table 2 also shows the Taguchi L9 array. 
Table 1. Factors and levels investigated in this study by the Taguchi method.

\begin{tabular}{|cccccc|}
\hline Factor & \multicolumn{4}{c}{ level } \\
\hline $\mathrm{NaOH}(\mathrm{M})$ & & $1-$ & 0 & $1+$ \\
\hline Time (hour) & $\mathrm{A}$ & 2 & 4 & 6 \\
\hline Temperature ${ }^{\circ} \mathrm{C}$ ) & $\mathrm{B}$ & 1 & 3 & 5 \\
\hline $\mathrm{NaOH} /$ Biomass & $\mathrm{C}$ & 30 & 60 & 90 \\
\hline & $\mathrm{D}$ & 1.15 & 1.20 & 1.25 \\
\hline
\end{tabular}

Table 2. Taguchi L9 array layout for chitosan production.

\begin{tabular}{|c|cccc|}
\hline Run & NaOH & Time & Temperature & NaOH/Biomass \\
\hline $\mathbf{1}$ & 1 & 3 & 3 & 3 \\
\hline $\mathbf{2}$ & 2 & 2 & 3 & 3 \\
\hline $\mathbf{3}$ & 2 & 1 & 2 & 1 \\
\hline $\mathbf{4}$ & 3 & 3 & 2 & 2 \\
\hline $\mathbf{6}$ & 1 & 2 & 2 & 3 \\
\hline $\mathbf{7}$ & 3 & 2 & 1 & 2 \\
\hline $\mathbf{8}$ & 2 & 3 & 1 & 1 \\
\hline
\end{tabular}

\section{Characterization of Chitosan by Fourier Transform Infrared Spectrometry Analysis}

Using FTIR to investigate chemical bonds and functional groups, the chitosan powder produced was prepared for FTIR test and the following equation was used to determine the degree of deacetylation of the samples (13).

(Equation1):

$\left.D D=\left[\left(A_{1655} \div A_{3450}\right)\right] \times 115\right]$

In this formula A1655 is the first type of Amide absorption peak at $1655 \mathrm{~cm}-1$ as the amount of $\mathrm{N}$ acetyl groups and $\mathrm{A} 3450$ is the Hydroxyl group $(\mathrm{OH})$ absorption peak at $3450 \mathrm{~cm}-1$ (14).

\section{Evaluation of Antibacterial Properties of Chitosan}

Disk diffusion method was used to evaluate the antibacterial activity of chitosan produced and two bacteria E. coli and S. aureus were studied (15).

\section{Statistical Analysis}

According to the data obtained from ANOVA in Table 4 and the results obtained from the experiments, a very high degree of similarity and agreement was observed $(p<0 / 05)$. Therefore, the variables listed in Table 4 are important and effective in producing more chitosan.

\section{Results}

Chitosan Extracted from the Native Trametes versicolor Fungus of Iran

After 10 days of cultivation of Trametes versicolor in PDB medium, the biomass (dry -weight) was $2.25 \mathrm{~g} / \mathrm{L}$.
The obtained biomass of $0.18 \mathrm{gr}$ of chitin and the obtained chitin of $0.09 \mathrm{gr}$ were finally extracted. Table 3 shows the amount of chitosan produced in each experiment. The purpose of the design of the experiment was to achieve the maximum chitosan content.

Optimization of Parameters Affecting the Production of Chitosan from the Medicinal Fungus Trametes versicolor

Four factors of $\mathrm{NaOH}$, time, temperature and biomass / $\mathrm{NaOH}$ ratios were selected to investigate the factors affecting chitosan growth. After selecting the factors, the experiments were designed and implemented using the Taguchi method in three levels with four factors. Chitosan production was then expressed in $\mathrm{g} / \mathrm{L}$.

According to the data obtained from ANOVA, a high degree of similarity and agreement is observed. Contour (C) shows a comparison chart of the results obtained from the amount of chitosan from the fungus in each experiment with data predicted by the software. As shown in Figure 1, the results of the experiments are highly consistent with the data predicted by the software, with R2 producing chitosan 0.9993 and R2 adjusted 0.9971, all of which indicate high accuracy of the experiments. Factors affecting $p$ value are less than 0.05 . The final equation for chitosan production is:

(Equation 2): chitosan $=+0.27-0.050 \mathrm{NaOH}-0 / 0656$ Time +0.000878 temperature $+0.0197 \mathrm{NaOH} \times$ Time 
Table 3. Data obtained from Taguchi method of chitosan production test

\begin{tabular}{|c|c|c|c|c|c|c|}
\hline \multirow[b]{2}{*}{ Run } & \multicolumn{4}{|c|}{ conditions } & \multicolumn{2}{|c|}{ Response } \\
\hline & $\begin{array}{c}\mathrm{NaOH} \\
\text { (M) }\end{array}$ & Time (h) & 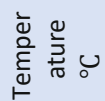 & $\mathrm{NaOH} /$ Biomass & Actual chitosan (g/l) & Predicted chitosan ( $\mathrm{g} / \mathrm{l})$ \\
\hline 1 & 1 & 3 & 3 & 3 & 0.12 & 0.1207 \\
\hline 2 & 2 & 2 & 3 & 1 & 0.135 & 0.1337 \\
\hline 3 & 2 & 1 & 2 & 3 & 0.137 & 0.1377 \\
\hline 4 & 3 & 3 & 2 & 1 & 0.23 & 0.237 \\
\hline 5 & 1 & 2 & 2 & 2 & 0.156 & 0.1547 \\
\hline 6 & 3 & 2 & 1 & 3 & 0.157 & 0.1557 \\
\hline 7 & 2 & 3 & 1 & 2 & 0.172 & 0.1727 \\
\hline 8 & 1 & 1 & 1 & 1 & 0.115 & 0.1157 \\
\hline 9 & 3 & 1 & 3 & 2 & 0.11 & 0.1107 \\
\hline
\end{tabular}

Table 4. ANOVA data for the variables used in the experiment

\begin{tabular}{|c|c|c|c|c|c|c|c|}
\hline Respond & Level & $\begin{array}{c}\text { Degree of } \\
\text { release }\end{array}$ & F-value & P-value & $\mathbf{R}^{2}$ & Obtained $\mathbf{R}^{2}$ & Predicted $\mathbf{R}^{2}$ \\
\hline & $\mathrm{A}-\mathrm{NaOH}$ & 1 & 468.17 & 0.00211 & \multirow{5}{*}{ 0/999 } & \multirow{5}{*}{ 0/9971 } & \multirow{5}{*}{$0 / 809$} \\
\hline \multirow{4}{*}{ 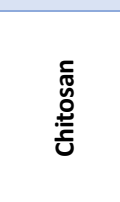 } & B-Time & 1 & 1066.17 & 0.00091 & & & \\
\hline & C-Temprature & 1 & 260.04 & 0.00381 & & & \\
\hline & D- Biomass $/ \mathrm{NaOH}$ & 2 & 198.05 & 0.0050 & & & \\
\hline & $A B$ & 1 & 780.12 & 0.0013 & & & \\
\hline & model & 6 & 460.17 & 0.0022 & & & \\
\hline
\end{tabular}

According to Cantor Figure 1: A) 2D and B) 3D chart shows the amount of chitosan production due to the interaction of the test factors, which increased with increasing $\mathrm{NaOH}$ concentration and the time of production of chitosan. The optimum test conditions for $\mathrm{NaOH}$ concentration, time, temperature and biomass to $\mathrm{NaOH}$ ratio were $5.94 \mathrm{M}, 4 \mathrm{~h}$ and $40 \mathrm{~min}$, $65.6^{\circ} \mathrm{C}$ and $1: 25 \mathrm{w} / \mathrm{v}$ ratio (Table 5).

Table 5. Optimized results of software Taguchi analysis

\begin{tabular}{c|cccc|c|}
\hline $\begin{array}{c}\text { The optimal } \\
\text { value of run } \\
\text { conditions }\end{array}$ & $\mathrm{NaOH}(\mathrm{M})$ & Time $(\mathrm{h})$ & Temperature $(\mathrm{C})$ & $\mathrm{NaOH} /$ Biomass & Chitosan $(\mathrm{g} / \mathrm{l})$ \\
\hline
\end{tabular}

(A)

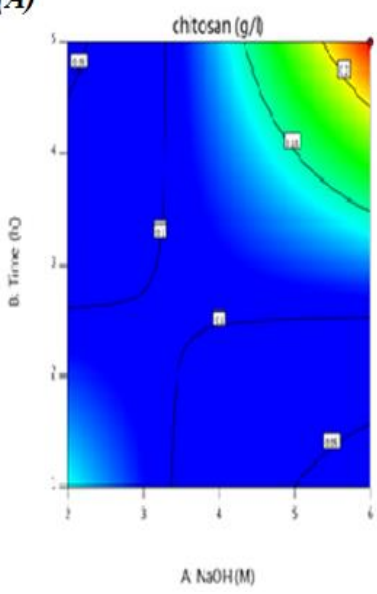

(B)

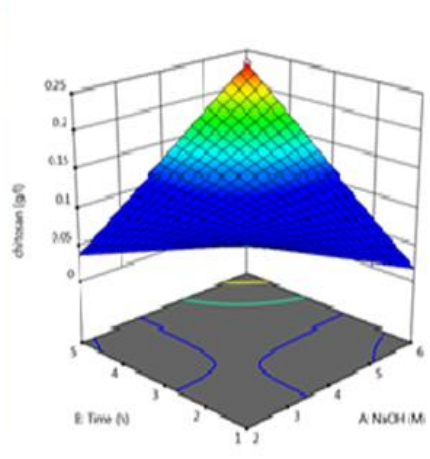

(C)

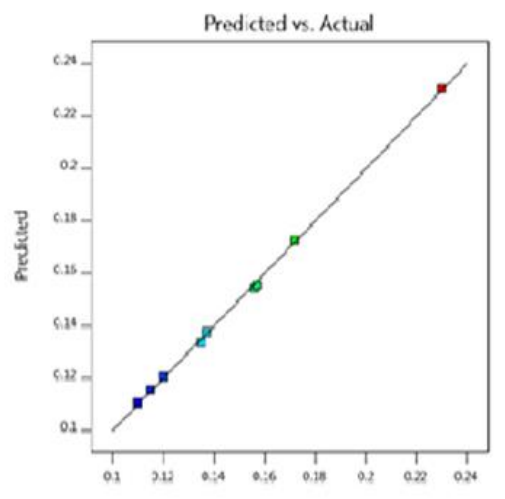

Actual

Figure 1. (A) two-dimensional diagram and (B) three-dimensional diagram of chitosan production with respect to the interaction of two time parameters and $\mathrm{NaOH},(\mathrm{C})$ Comparison diagram of the amount of chitosan produced and predicted. 


\section{FTIR Spectrum}

For a closer look, the FTIR spectrum was taken from the commercial chitosan sample and compared with the chitosan sample produced from the fungus. Figure 2 , shows the FTIR spectra of chitin and fungal chitosan. In the process of deacetylation of the chitin, the bonds of the $1655-\mathrm{cm}^{-1}$ region are gradually reduced while the band-area of $1558-\mathrm{cm}^{-1}$ is increased due to the presence of $-\mathrm{NH}_{2}$ groups. The band of $1558 \mathrm{~cm}^{-1}$ shows higher adsorption than $1655 \mathrm{~cm}^{-1}$, indicating an effective deacetylation of chitin. To determine the degree of deacetylation the first type amide bands in the $1655 \mathrm{~cm}^{-1}$ region and the $-\mathrm{OH}$ tensile bands in the $3450 \mathrm{~cm}^{-1}$ regions are crucial. The peak in the $1250 \mathrm{~cm}^{-1}$ region corresponds to the amino groups present in the chitosan structure.

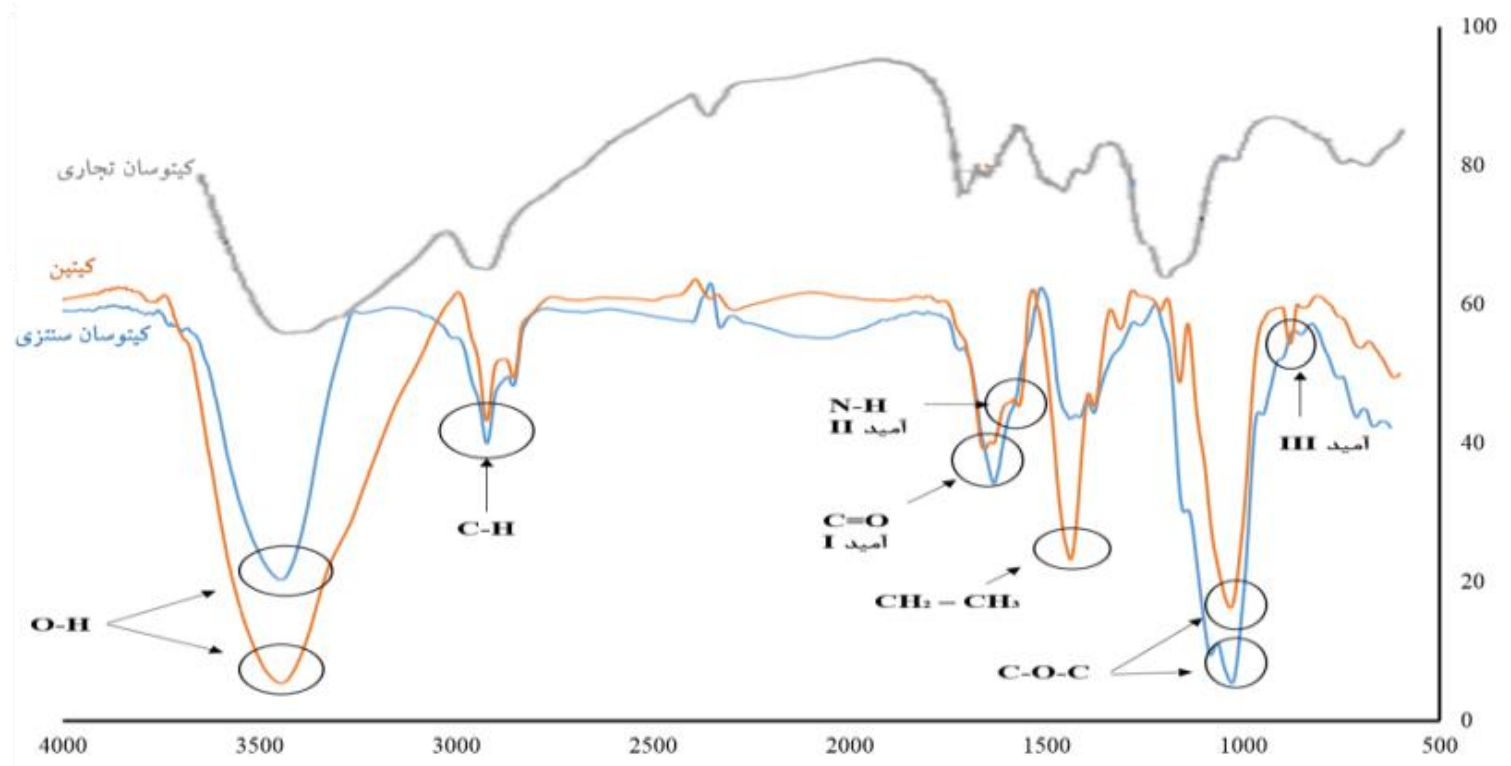

Figure 2. FTIR spectrum of chitin and extracted chitosan with commercial chitosan

\section{Determination of the Degree of Chitosan Deacetylation Extracted}

Based on the infrared curves obtained, equation 1 degree of commercial chitosan deacetylation, $76 \%$ was obtained, and the degree of produced chitosan deacetylation was $78 \%$.

\section{Evaluation of the Antibacterial Activity of Chitosan Produced from Native Trametes versicolor}

Antibacterial disk test was performed against Grampositive Staphylococcus aureus and Gram-negative bacteria Escherichia coli after chitosan production from
Trametes versicolor. To do this, chitosan extracted from the fungus was compressed into a tablet of the specified size. The aura created on the margin of the chitosan tablet indicates its antibacterial activity. Chloramphenicol antibiotics were used to control the test. All steps were performed with three replications. The antibacterial activity against $S$. aureus is higher than that of $E$. coli, indicating a higher chitosan efficacy than Gram-positive bacteria. The results of bacterial immunity in the disk diffusion test are presented in Table 6. Compared with chloramphenicol, $S$. aureus showed a greater inactivation in the application of chitosan synthesized from fungi than in $E$. coli.

Table 6. Bacterial non-growth rate in $\mathrm{mm}$ in disk diffusion test

\begin{tabular}{|c|c|c|}
\hline Samples & Escherichia coli & Staphylococcus aureus \\
\hline Fungal chitosan & $1(\mathrm{~mm}) \pm 12$ & $\mathbf{2}(\mathbf{m m}) \pm \mathbf{1 8}$ \\
\hline Chloramphenicol & $2(\mathrm{~mm}) \pm 23$ & $\mathbf{3}(\mathbf{m m}) \pm \mathbf{2 1}$ \\
\hline
\end{tabular}

\section{Discussion}

In this study, the chitosan of the medicinal fungus Trametes versicolor was optimized by the Taguchi method. The optimum conditions for $\mathrm{NaOH}$ concentration, time, temperature and biomass to $\mathrm{NaOH}$ ratio were $5.94 \mathrm{M}, 4 \mathrm{~h}$ and $40 \mathrm{~min}, 65.6^{\circ} \mathrm{C}$ and ratio of 1 to $25 \mathrm{w} / \mathrm{v}$, respectively. After chitin deacetylation by 
concentrated sodium hydroxide at $90^{\circ} \mathrm{C}$, FTIR spectroscopy shows that this method had more effect on $\mathrm{N}-\mathrm{H}, \mathrm{O}-\mathrm{H}$, and $\mathrm{C}-\mathrm{H}$ peaks. These changes in absorption indicate that alkaline and heat have eliminated the acetyl group from the chitin sample and the production of chitosan. Chitin is composed of $\mathrm{OH}, \mathrm{NHCOCH}_{3}$, and $\mathrm{NH}_{2}$ groups and is eliminated by deacetylation so chitosan is obtained with $\mathrm{OH}$ and $\mathrm{NH}_{2}$ functional groups (16). Increasing the amount of alkali to $5.9 \mathrm{M}$ concentration at $65^{\circ} \mathrm{C}$ increased protein degradation and more effective interactions on mycelium and chitin and ultimately more chitosan production.

Based on some researchers in optimizing chitin and chitosan production and comparing with the results of the present study, most of the work done on PDB medium has been used to grow fungi. In 2008, Wang et al. investigated the physical properties of chitosan fungi on Absidia coerulea, Mucor rouxii, Rhizopus oryzae, with chitosan acetylation rates of these fungi above $80 \%$ (17). This difference in the degree of deacetylation can be explained by the structure of the extracted chitosan, the degree of purity and the molecular weight of the chitosan which can be varied in other fungi. The results of bacterial Inhibition in the disk diffusion assay show that in general the gram-negative bacteria have more sequence in the membrane itself than the cell membrane layers and consequently have thicker membrane than the Gram-positive bacteria. Increased membrane strength of Gram-negative bacteria and consequently increased resistance to antibacterial agents. In 2001, Kim WJ and colleagues extracted and optimized Chitosan from the fungus Absidia coerulea, with an optimum value of $2.3 \mathrm{~g} / \mathrm{L}$ (18). Also in 2009, Andipan et al. from Mucor rouxii increased chitosan production by adding molasses salt from $14.7 \%$ to $36.4 \%$ chitosan levels with deacetylation degree: $12.8 \%$ and molecular weight: $2.48 \times 104$ (19). In 2017, AbdelGawad and his colleagues obtained Aspergillus niger chitosan with an acetylation degree of $83.64 \%$ (14).
In 2018, Ahamed MIN and et al., investigated the production of chitosan from crab bark using sonicate waves to antibacterial activity in the resulting chitosan disc diffusion test, the growth zone diameter for $S$. aureus and $E$. coli, respectively, $12 \mathrm{~mm}$ and $14 \mathrm{~mm}$ were obtained (24). In 2019, Kulawik et al., in a review article on the role of chitosan on seafood found that higher deacetylate chitosan showed the best adsorption on Gram-negative and Gram-positive bacteria and lower $\mathrm{pH}$ of chitosan by bacterial cells were Improved (25).

\section{Conclusion}

In this study, the Iranian fungus Trametes versicolor was used and the Taguchi method was used to optimize chitosan from this fungus, which is a reason for its innovation. The results showed a high percentage of similarity of chitosan produced by fungi and commercial specimens purchased and samples in research papers. Bacterial immunity against $E$. coli and S. aureus in millimeters were $12 \pm 1$ and $18 \pm 2$, respectively, indicating a greater efficacy on Grampositive bacteria. Chitosan extraction from fungi, optimum test conditions for $\mathrm{NaOH}$ concentration, time, temperature and biomass to $\mathrm{NaOH}$ ratio were $5.94 \mathrm{M}$, $4 \mathrm{~h}$ and $40 \mathrm{~min}, 65.6^{\circ} \mathrm{C}$ and $1: 25$ ratio, respectively. The chitosan concentration in this condition was $0.261 \mathrm{~g} / \mathrm{L}$.

\section{Acknowledgment}

The results obtained from a Master thesis with identification code 15730560962049 at Islamic Azad University North Tehran Branch.

\section{Conflict of Interest}

Authors declared no conflict of interests. 


\section{مجله مبكروبشناسي بزيكى ايران

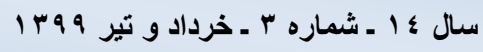 \\ Journal homepage: $\underline{w w w . i j m m . i r}$}

بهينه سازى توليد كيتوسان از قارج دارويى تراميتيس ورسيكالر بومى ايران به روش تاكوجى و بررسى خاصيت ضدباكتريايى

\section{نكَين يثربى'، اشرف السادات حاتميان زارمى" ‘، محدثه لارى يور}

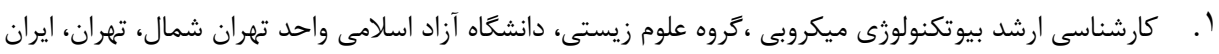

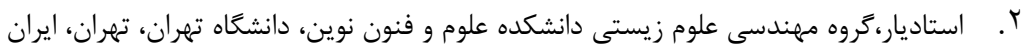

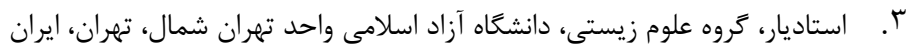

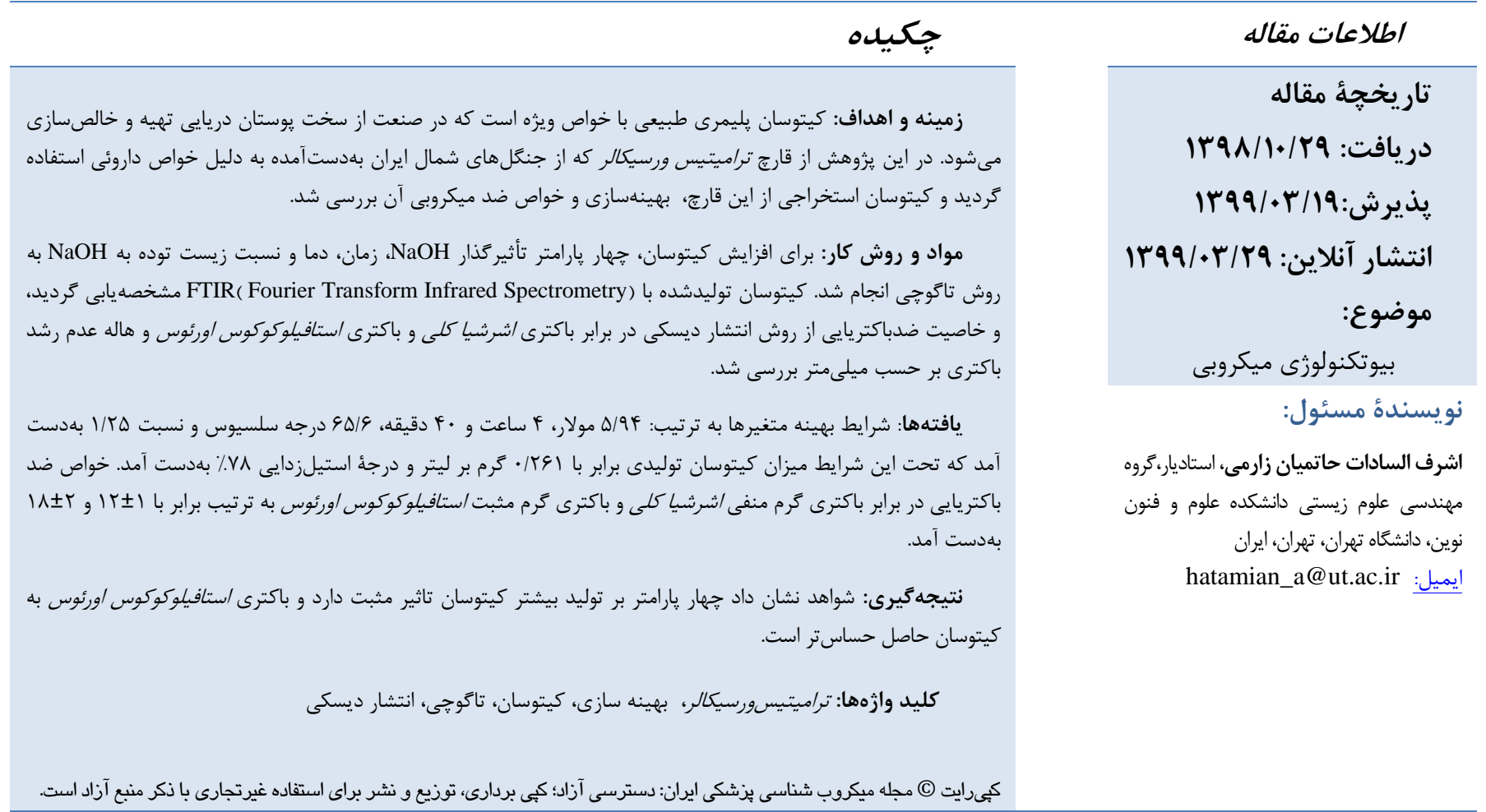

مقدمه

بيمارىهاى قلبى اشاره كرد. همينطور منبع با ارزشى از تركيبات

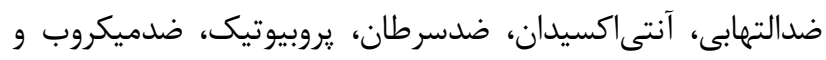
ضدديابت بهشمار مىروند (ץ). قارج تراميتيس ورسيكالر كه با اسامى كوريولوس ورسيكالر يا يليبيوراس ورسيكالر در كشورهاى

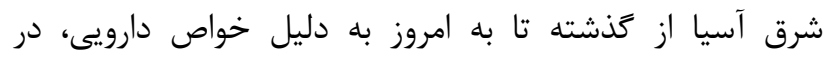

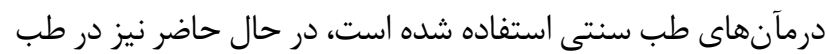
نوين استفاده دارد. اين قارج در سراسر جهان بهخصوص در نيمكره

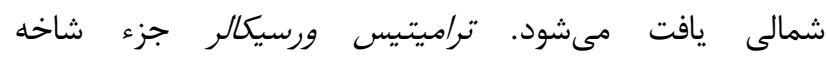
بازيديومايكوتاها و خانواده يلى يور/سها است. اين قارج داراى اجزاى
قارجها به دليل ويزگىهاى منحصر به فرد خود در بين محققان و جوامع علمى مورد توجه هستند. همينطور زونههايى از قارجهاى وحشى در برخى جوامع بهصورت تجارى كشت داده

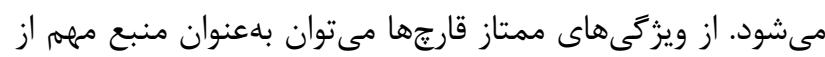
تركيبات فعال زيستى با ارزش دارويى اشاره كرد كه توجه بسيارى از محققان سراسر دنيا را به خود معطوف كرده است (1). ازجمله اين بردئ خواص دارويى فيزيولوزيكى مىتوان به افزايش سطح ايمنى، تنظيم ضربان قلب، درمان و ريشخيرى از بيمارىهاى مختلف، بهبود بيمارىهاى تهديدكننده زندگى مثل سرطان، سكته مغزى و و Majallah-i mīkrub/shināsī-i pizishkī-i Īrān. 
تراميتيس ورسيكالر بومى ايران كه از جنكلهاى شمال ايران

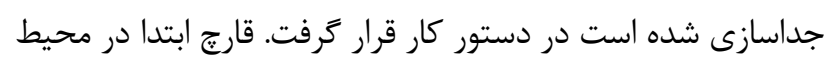

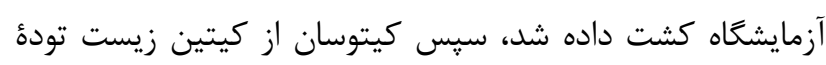

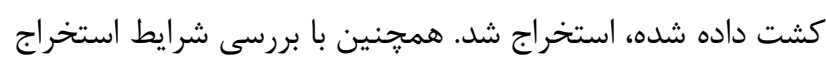

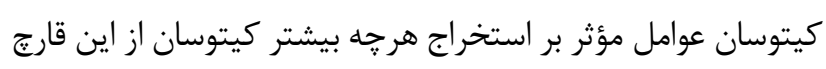

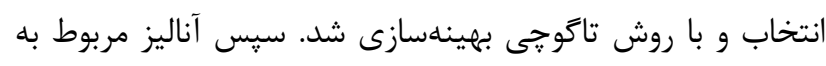

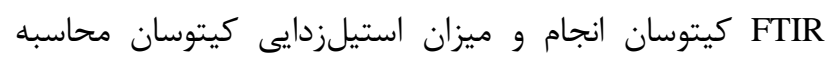

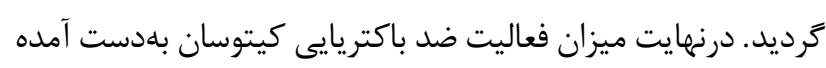
با استفاده از روش انتشار ديسكى محاسبه كرديد.

\section{روش : بزوهش}

مواد استفاده شده در اين يزوهش شامل قارج تراميتيس

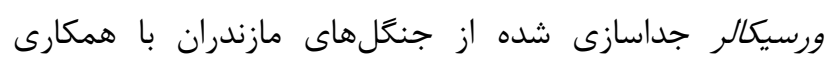

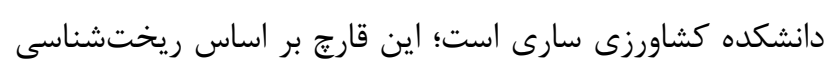

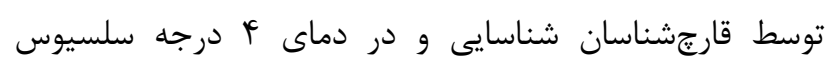

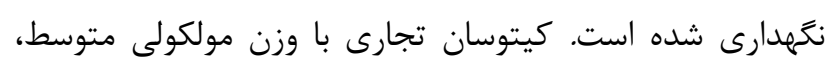

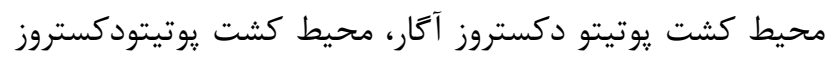

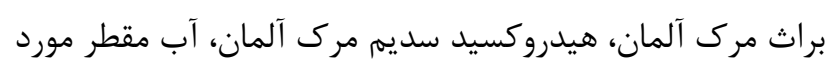

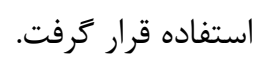

\section{كشت قارج و استخراج كيتين وكيتوسان}

قارج تراميتيس ورسيكالر براى نكهدارى در شرايط آزمايشگاهى، در محيط Potato dextrose agar) PDA)(توليد

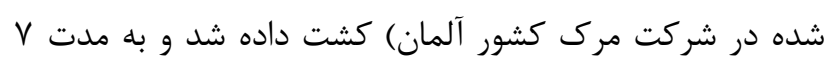

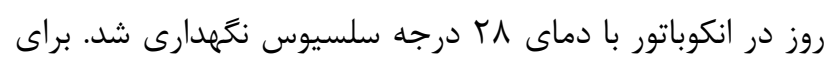

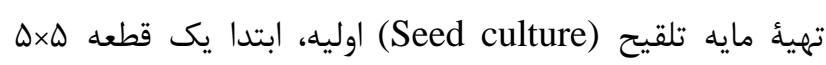

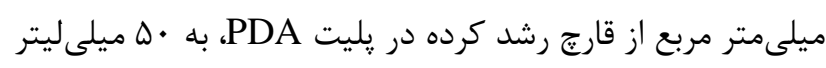

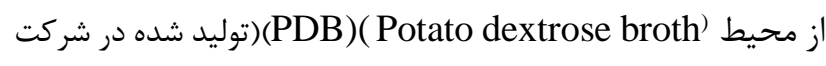

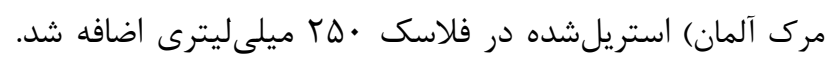

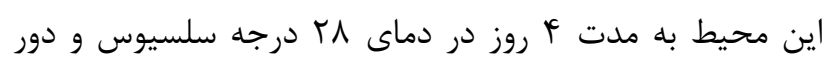

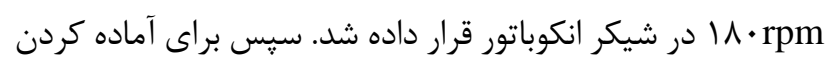

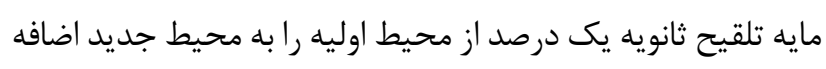

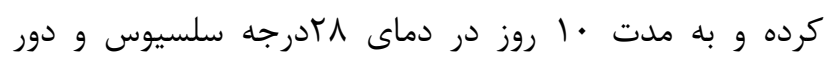

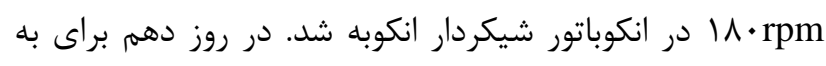

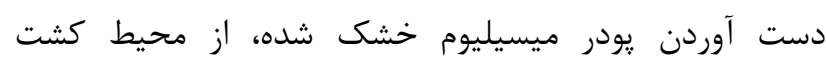

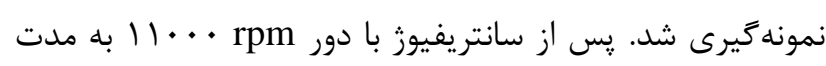

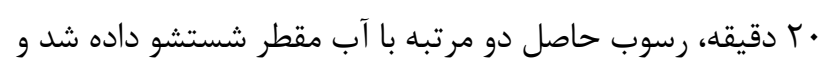

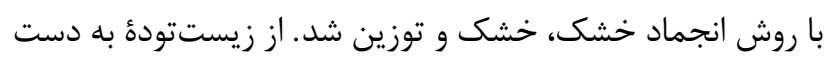

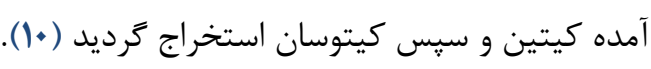

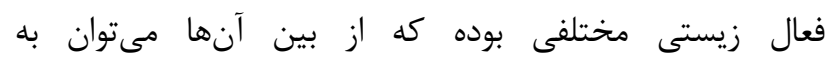

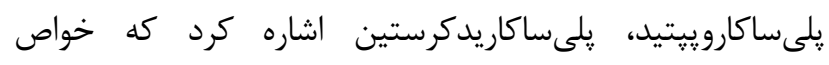

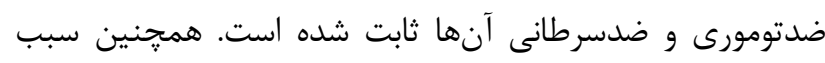

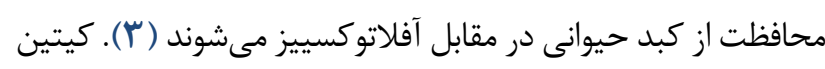

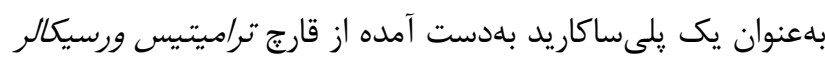
است كه بهعنوان ماده خام تجارى براى توليد كيتوسان و كلوكز آمين درنظر كرفته مىشود. كيتوسان از طريق داستيله شدن بازئ بازى كيتين

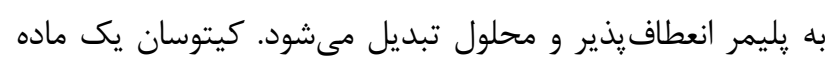

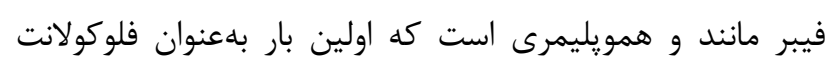

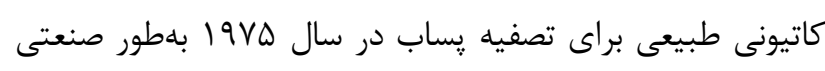

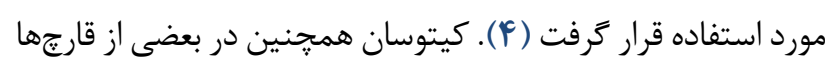
يافت مىشود و به دليل خصوصيات ويزٔه خود از قبيل ساختار

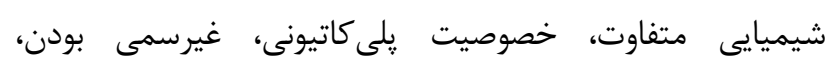
زيست تخريبيذيرى، زيستساز

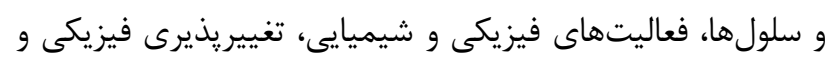

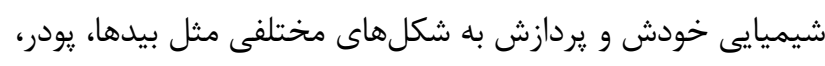

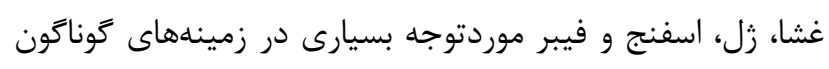

قرار مى گيرد (ه, (ه).

اين خصوصيات منحصربهفرد، موجب شد تا كيتوسان توجه

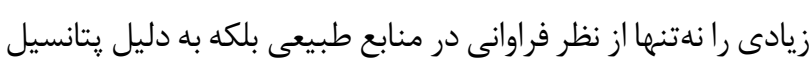

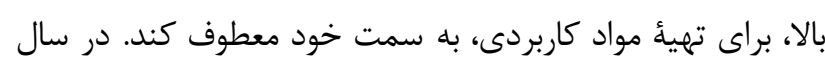

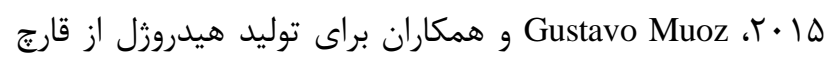

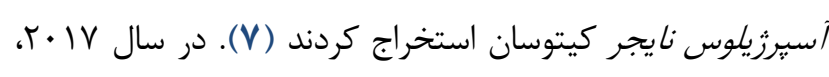
Sathiyaseelan

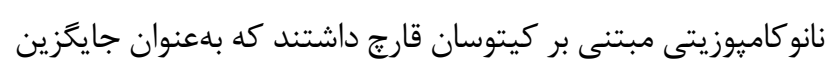

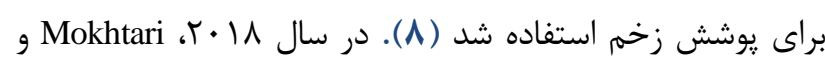

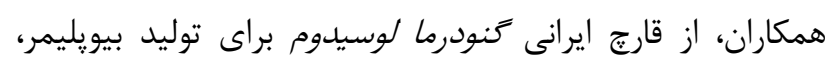

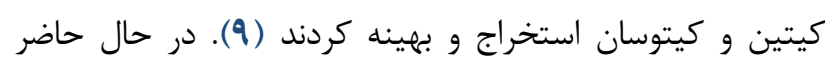

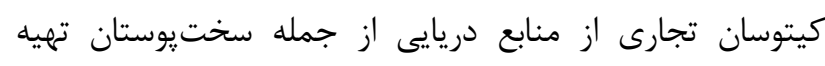

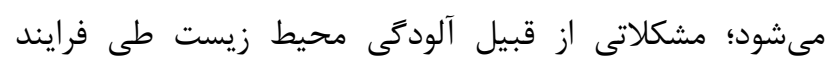

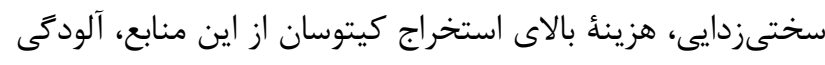

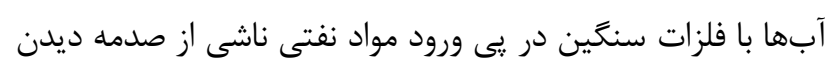

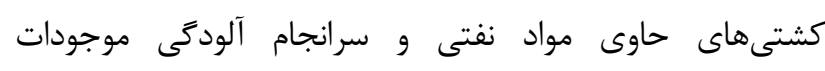

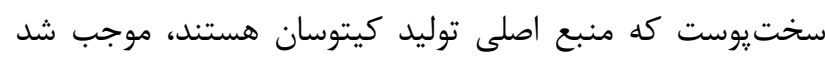

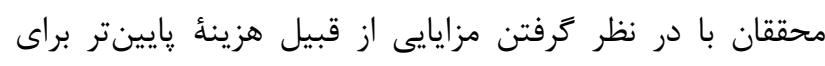

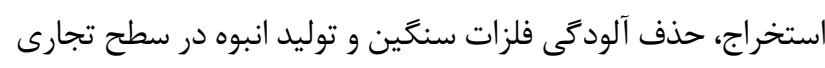

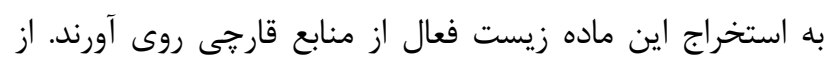

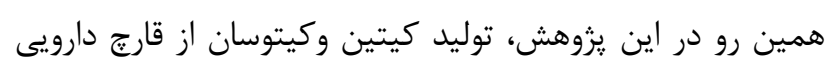


حالتى خنثى بيدا كند. درنهايت كيتوسان حاصل همانند كيتين با آنا

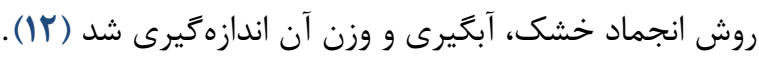

\section{بهينهسازى متغيرهاى محيطى مؤثر بر فرايند} جداسازى و توليد كيتوسان از تراميتيس ورسيكالر

با توجه به روشهاى رايج مورداستفاده براى طراحى آزمايش

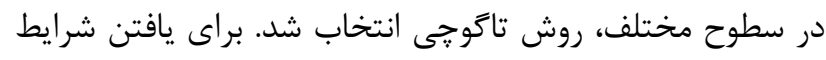
بهينه توليد بيشتر كيتوسان، برخى از يارامترهاى مؤثر در استخراج

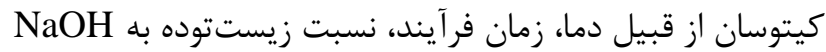

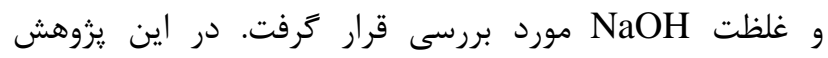

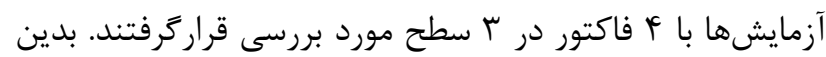

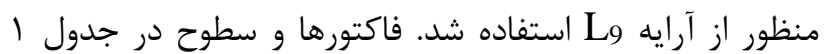

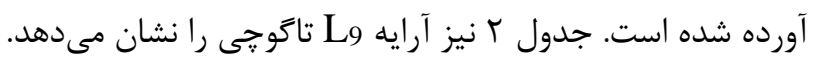

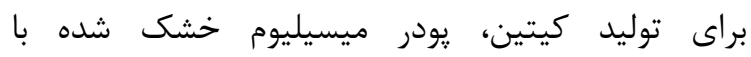

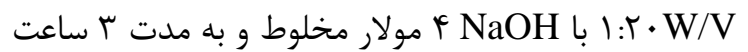

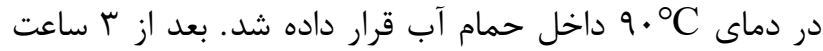

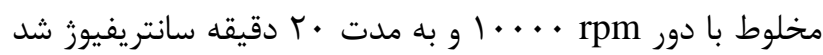

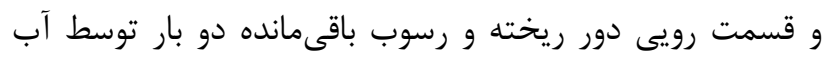
مقطر شسته و سانتريفيوز شد. رسوب باقىمانده كه همان كيتين

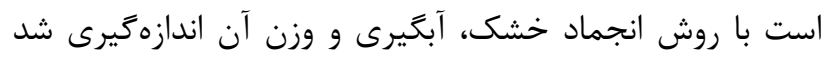

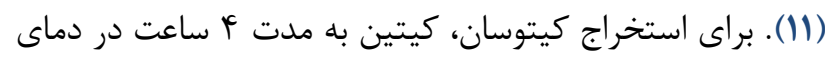

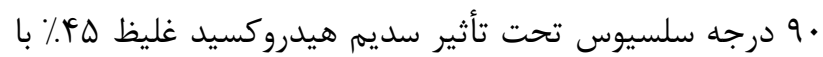

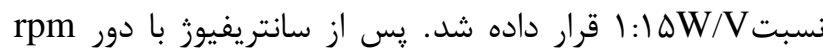

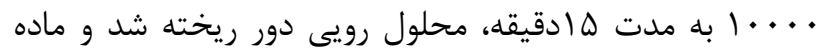

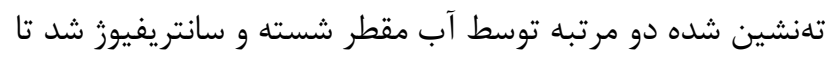

جدول ا. فاكتورها و سطوح موردبر سى در اين تحقيق با استفاده از روش تاكوجى

\begin{tabular}{|c|c|c|c|c|}
\hline \multirow{2}{*}{ فاكتور } & \multicolumn{4}{|c|}{ 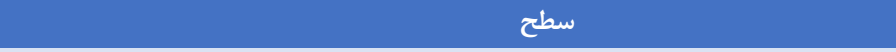 } \\
\hline & & -1 & - & +1 \\
\hline (مولار) & A & $r$ & r & 4 \\
\hline زمان (ساعت) & B & 1 & r & 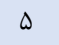 \\
\hline دما (درجه سلسيوس) & $\mathrm{C}$ & $r$. & 9. & 9. \\
\hline زNaOH زيست تودها & D & $1 / 10$ & $1 / \pi$. & $1 / \pi \Delta$ \\
\hline
\end{tabular}

جدول r. جيدمان آرايه L تاكوجى براى توليد كيتوسان

\begin{tabular}{|c|c|c|c|c|}
\hline \multirow{2}{*}{ آزمايش } & \multicolumn{4}{|c|}{ شرايط آزمايش } \\
\hline & $\mathrm{NaOH}$ & زمان & Los & زيست توده/NaOH \\
\hline 1 & 1 & r & r & $r$ \\
\hline$r$ & r & r & $r$ & 1 \\
\hline$r$ & r & 1 & r & r \\
\hline r & r & r & r & 1 \\
\hline$\Delta$ & 1 & $r$ & r & r \\
\hline 9 & $r$ & r & 1 & $r$ \\
\hline v & r & $r$ & 1 & r \\
\hline$\wedge$ & 1 & 1 & 1 & 1 \\
\hline 9 & $r$ & 1 & $r$ & r \\
\hline
\end{tabular}

براى تعيين درجه استيلزدايى مقدار ها ميلى كرم از يودر

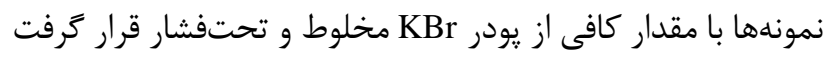

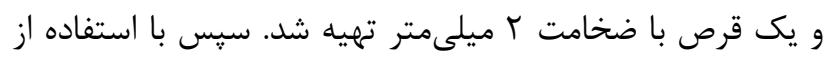

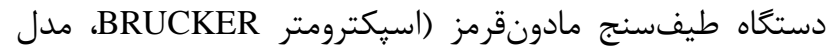

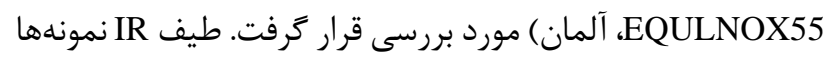

مشخصه يابى كيتوسان با آناليز طيفسنجى مادون قرمز طيفسنجى مادون قرمز (FTIR) روشى رايج براى مطالعات

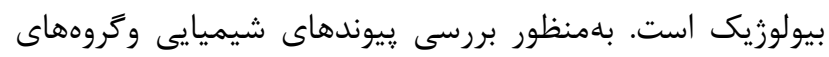
عاملى، يودر كيتوسان توليدشده به همراه نمونهٔ تجارى خريدارى برى بردي

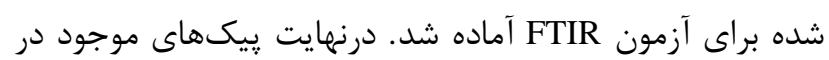
محدوده 
مىشود. (ه •/P<). بنابراين متغيرهاى درج شده در جدول أ در توليد بيشتر كيتوسان مهمر و اثر كذار هستند.

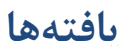

كيتوسان استخراجشده از قارج تراميتيس ورسيكالر

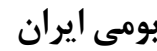

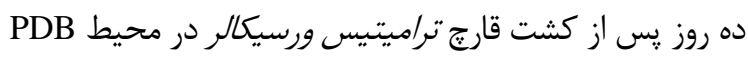

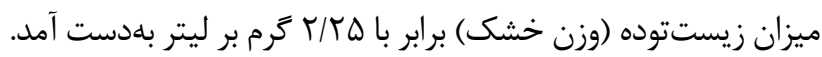

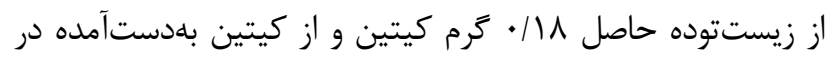

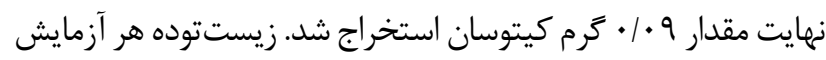
در روز هفتم از محيط كشت غوطهور جداسازى و براساس روش

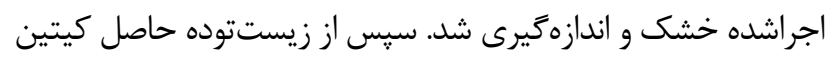

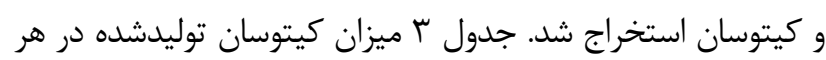

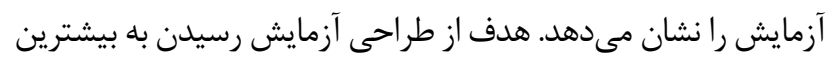
ميزان كيتوسان بوده است.

\section{بهينهسازى پارامترهاى موثر بر توليد كيتوسان از قارج \\ دارويى تراميتيس ورسيكالر}

با بررسىهاى صورت كرفته درباره عوامل تأثير تذار بر افزايش

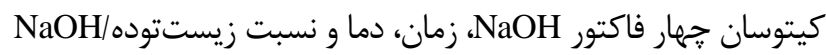

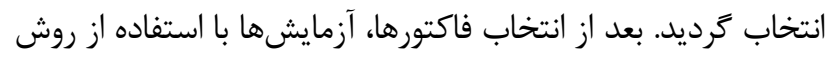

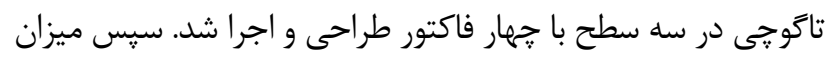
توليد كيتوسان برحسب g/L بهدست آمد.

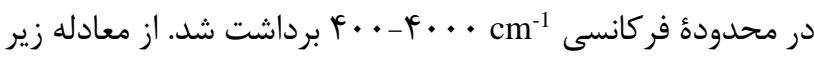
براى تعيين درجة استيلزدايى نمونهها استفاده شد.
$\left.\mathrm{DD}=\left[\left(\mathrm{A}_{1655} \div \mathrm{A}_{3450}\right)\right] \times 115\right]$
معادله (1)

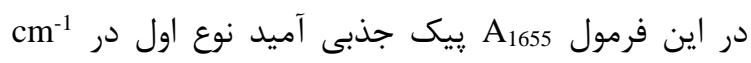

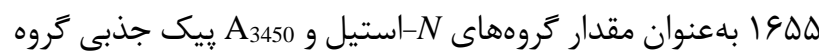

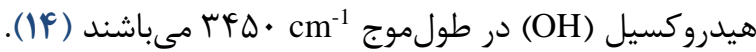

\section{بررسى خواص ضدباكتريايى كيتوسان}

جهت بررسى خاصيت ضدباكتريايى كيتوسان توليدشده از روش انتشار ديسكى استفاده شد و دو باكترى اشرشياكلى و استافيلوكوكوس /ورئوس بلعنوان نمايندة باكترىهاى گرم منفى و و

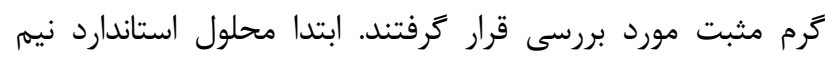

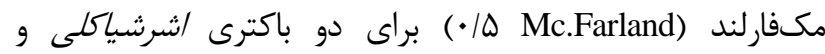

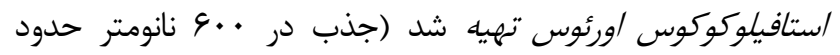

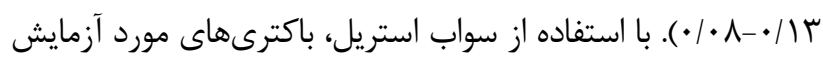

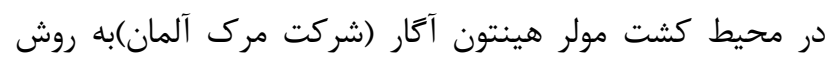

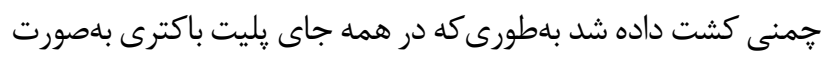

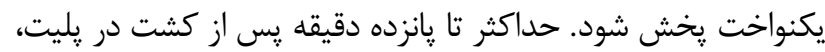

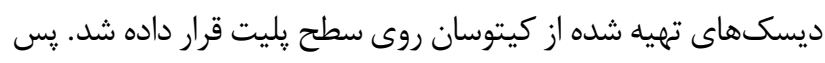

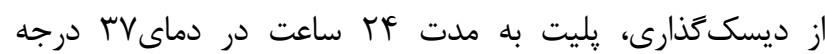
سلسيوس داخل انكوباتور قرار داده شد (ها).

\section{تجزيه و تحليل آمارى}

با توجه به دادههاى حاصل از ANOVA در جدول أز و نتايج

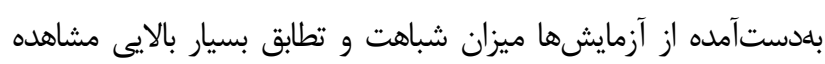

جدول r. دادهاى حاصل از انجام آزمايش توليد كيتوسان با روش تاگوجى

\begin{tabular}{|c|c|c|c|c|c|c|}
\hline \multirow[b]{2}{*}{ 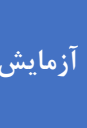 } & \multicolumn{4}{|c|}{ شرايط آزمايش } & \multicolumn{2}{|c|}{ ياسخ } \\
\hline & $\begin{array}{c}\mathrm{NaOH} \\
(\mathrm{M})\end{array}$ & 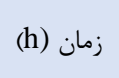 & ${ }^{\circ} \mathrm{Clos}$ & زيست زوده/NaOH & كيتوسان واقعى(g/l) & كيتوسان يِيشبينىشده (g/1) \\
\hline 1 & 1 & r & $r$ & r &.$/ 1 r$ & $\cdot / I T \cdot V$ \\
\hline$r$ & r & r & r & 1 & . IITA & . ITrV \\
\hline$r$ & $r$ & 1 & $r$ & r & $\cdot / 1 r v$ & $\cdot / 1 r V V$ \\
\hline f & r & $r$ & $r$ & 1 & $\cdot / \pi r$ & . \\
\hline$\Delta$ & 1 & r & $r$ & r & $\cdot / 1 \Delta \varphi$ & $\cdot / 1 \Delta F V$ \\
\hline 9 & $r$ & r & 1 & $r$ & $\cdot / 1 \Delta V$ & $\cdot / 1 \Delta \Delta V$ \\
\hline v & $r$ & r & 1 & r &.$/ I V T$ & - IIVTV \\
\hline$\wedge$ & 1 & 1 & 1 & 1 & .1110 & $\cdot / 11 \Delta V$ \\
\hline 9 & $r$ & 1 & $r$ & r & .111 & $\cdot / 11 \cdot v$ \\
\hline
\end{tabular}


بdعنوان مثال، R2 توليد كيتوسان R991/ و R2 تنظيمشده 99V/. كزارش شد. تمام اين اطلاعات نشان از دقت بالاى آزمايشهاى انجام شده داشت (ه • / > P). بنابراين متغيرهاى ذيل در توليد بيشتر كيتوسان مهم و

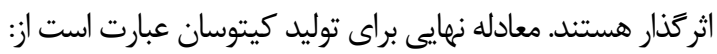

كانتور (C) نمودار مقايسه نتايج بلدستآمده از ميزان كيتوسان

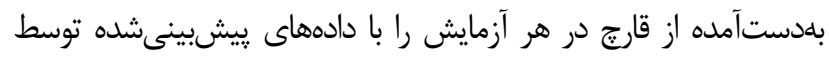
نرمافزار نشان مىدهد. همانطور كه در شكل ا نشان دادهشده است نتايج حاصل از آزمايشها به دادههاى يِيشبينى مُشده توسط نرمافزار شبيه بود.

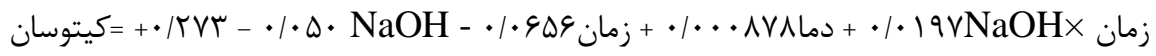

جدول F. داده هاى حاصل از ANOVA براى متغيرهاى مورد استفاده در آزمايش

\begin{tabular}{|c|c|c|c|c|c|c|c|}
\hline باسخ & سطح & درجه آزادى & F-value & P-value & $\mathbf{R}^{2}$ & به دست آمده R2 & بيش بينى شده R2 \\
\hline & $\mathrm{NaOH}-\mathrm{A}$ & 1 & FEN/IV & $\cdot / \cdot r \mid 1$ & \multirow{5}{*}{.$/ 999$} & \multirow{5}{*}{.$/ 9971$} & \multirow{5}{*}{$\cdot / 1 \cdot 9$} \\
\hline \multirow{5}{*}{\begin{tabular}{l}
$3:$ \\
$3:$ \\
3 \\
3 \\
\hdashline
\end{tabular}} & B-B زمان & 1 & $1.9911 \mathrm{~V}$ &. $\mid \cdots 91$ & & & \\
\hline & - دما -C & 1 & $r \varepsilon \cdot 1 \cdot r$ & $\cdot / \cdot r \wedge l$ & & & \\
\hline & 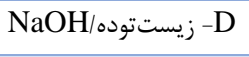 & r & $19 N / \cdot \Delta$ & $\cdot / \cdot \Delta$ & & & \\
\hline & $\mathrm{AB}$ & 1 & $V \Lambda \cdot / I T$ & . & & & \\
\hline & model & 9 & $49 . / 1 V$ & $.0 t r$ & & & \\
\hline
\end{tabular}

بهينهسازى انجامشده، شرايط آزمايش بهينه براى غلظت NaOH، زمان، دما و نسبت زيست زوده به NaOH به به

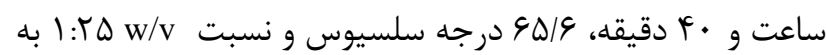

$$
\text { دست آمد (جدول ه). }
$$

طبق كانتورشكل I (A) نمودار دوبعدى و (B) نمودار سه بعدى ميزان توليد كيتوسان را با توجه به ميانكنش فاكتورهاى

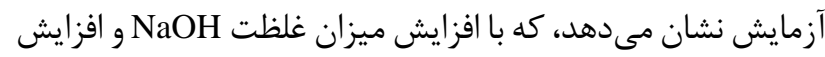
زمان، ميزان كيتوسان توليدى افزايشيافته است. بر اساس ميرن

\begin{tabular}{|c|c|c|c|c|c|}
\hline مقدار برينه شرايط & $\mathrm{NaOH}(\mathrm{M})$ & زمان (h) & دما ( & زيست توده/NaOH & كيتوسان (g/l) \\
\hline آزمايش & $\Delta / 9 \vdash \mathrm{M}$ & $f / f$. & $9 \Delta / 9$ & $1: r \Delta$ & $\cdot|r q|$ \\
\hline
\end{tabular}
جدول ه. نتايج بهينه شرايط حاصل از تحليل تاكوجى توسط نرمافزار
(A)

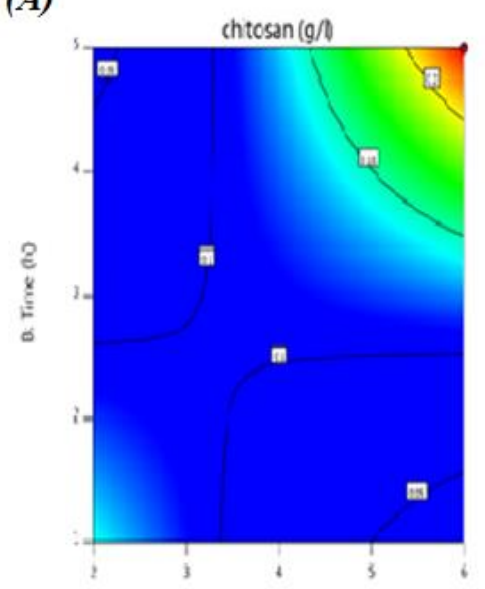

A NSOH(M)
(B)

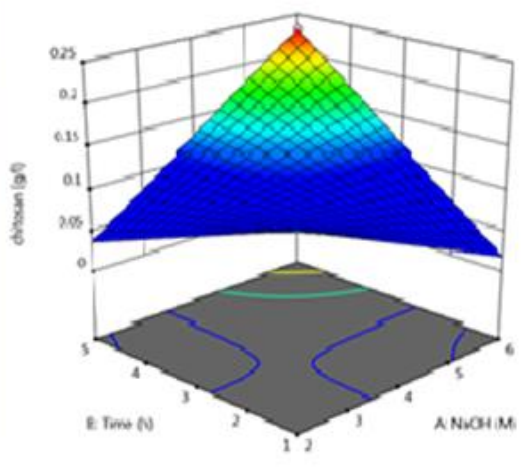

(C)

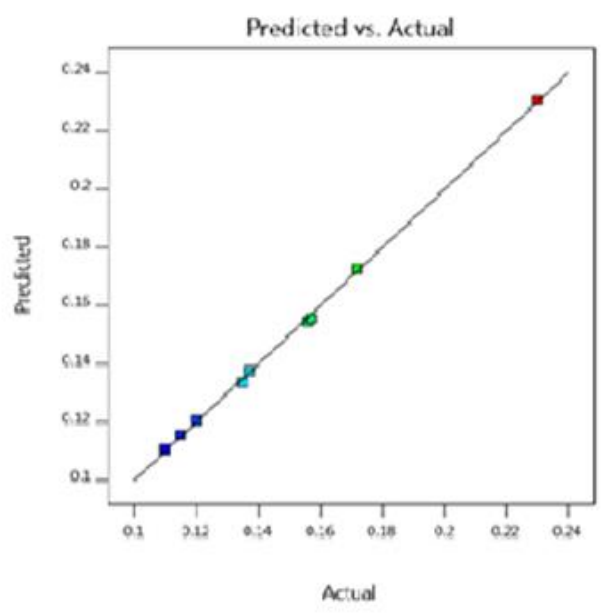

شكل ا. (A) نمودار دوبعدى و (B) نمودار سه بعدى توليد كيتوسان با توجه به ميانكنش دو پارامتر زمان و NaOH (C) Nقايسه ميزان كيتوسان توليدشده و بيشبينىشده 
لها با با تغيير شكلهاى NH

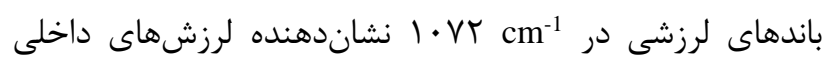

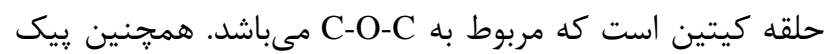

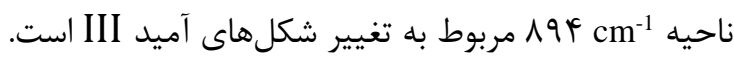
در فرآيند استيلزدايى از كيتين زيوندهاى ناحيه

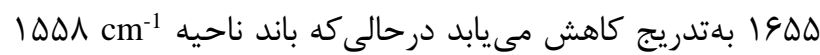
افزايش مىيابد كه به دليل وجود كروههاى NH

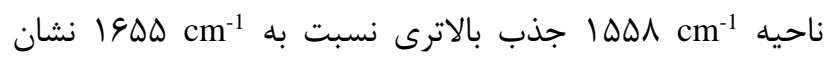

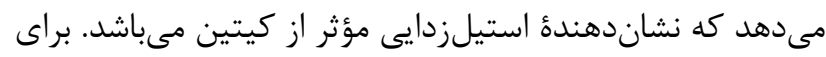
تعيين درجه استيلزدايى باندهاى آميد نوع اول در ناحيه

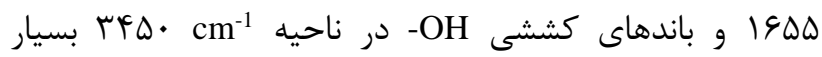
تعيين كننده هستند. ييك در آناحيه كروههاى آمينى موجود در ساختار كيتوسان است.

\section{FTIR Fيف}

براى بررسى يِيوندهاى شيميايى و گروههاى عاملى كيتوسان

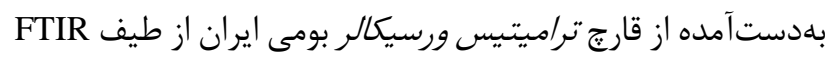
استفادهش. براى بررسى دقيق تر ازنمونه تجارى كيتوسان

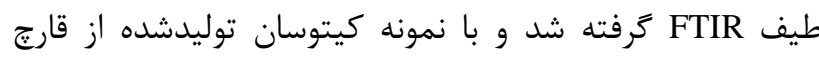
مقايسه كرديد.

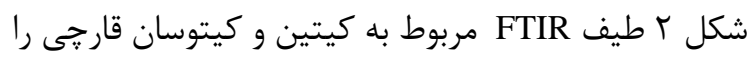
نشان مى دهد. در محدودة

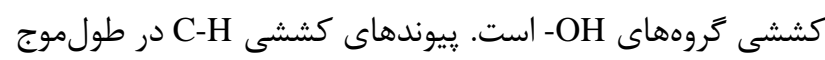
S ديد cm cm

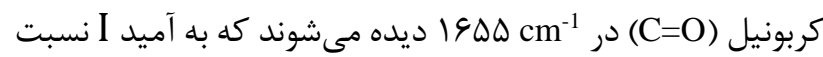

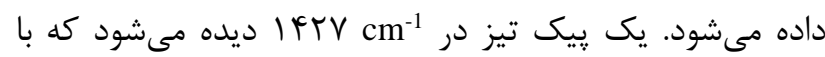
تغيير شكلهاى متقارن Cm

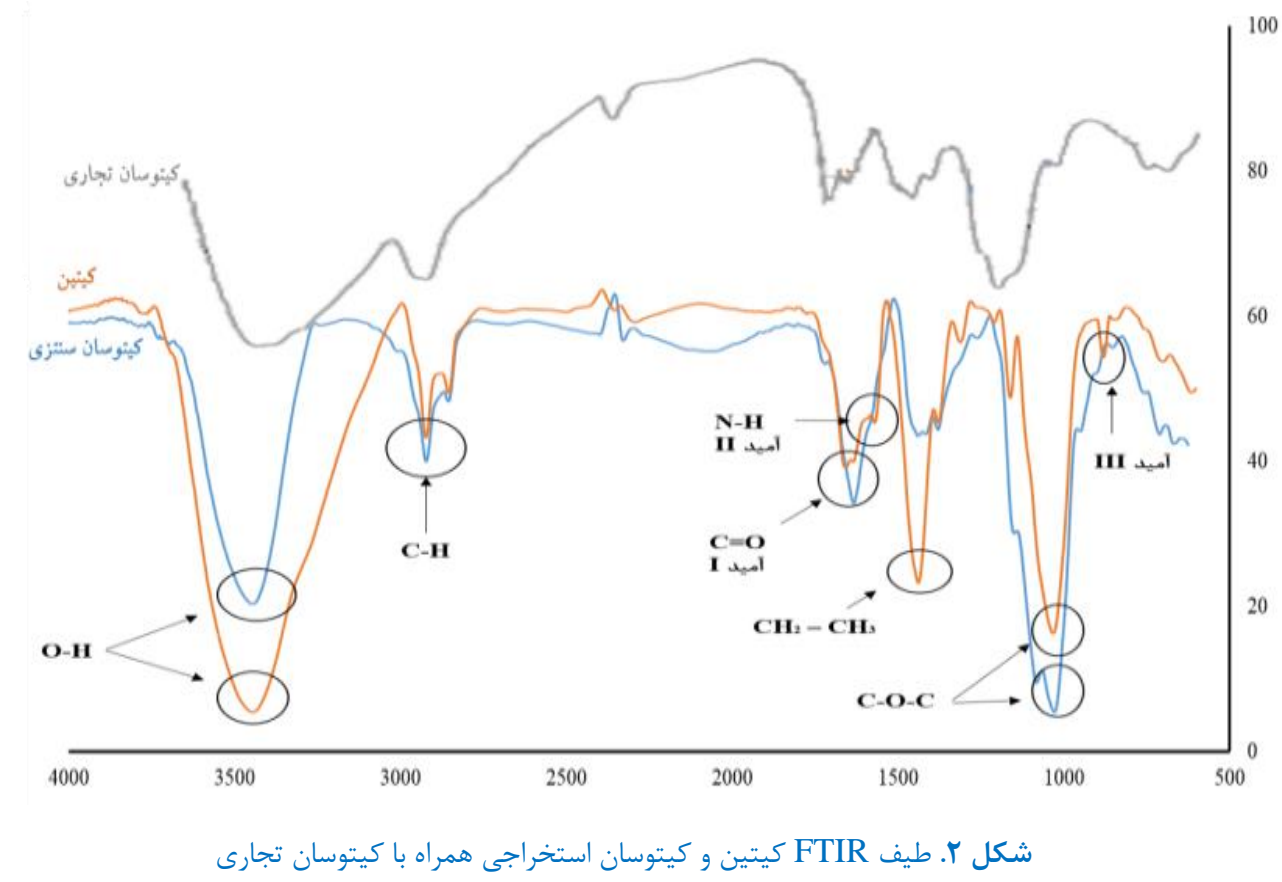

بررسى خاصيت ضدباكتريايى كيتوسان توليدشده از

$$
\text { قارج تراميتيس ورسيكالر بومى ايران }
$$

آزمون ضدباكتريايى ديسكى در برابر باكترى كرم مثبت

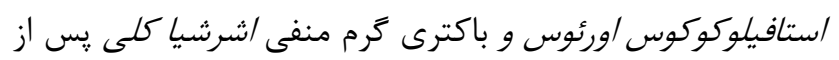

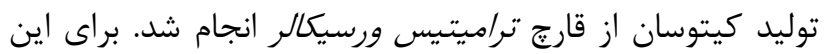

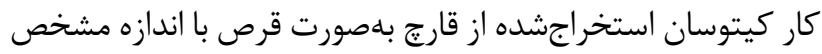

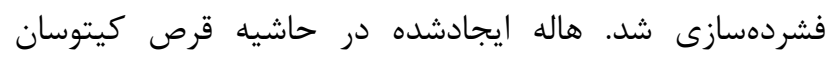

\section{تعيين درجه استيلزدايى كيتوسان استخراج شده}

براى تعيين درجه استيلزدايى باندهاى آميد نوع اول در ناحيه

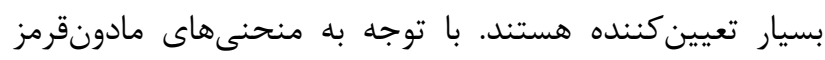
بهدستآمده و بر اساس معادله 1 درجه استيلزدايى كيتوسان

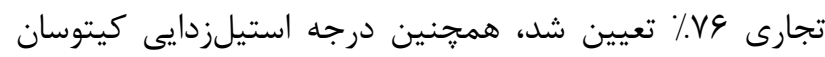

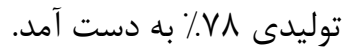


كرم مثبت دارد. نتايج ميزان عدم رشد باكترى در آزمون انتشار

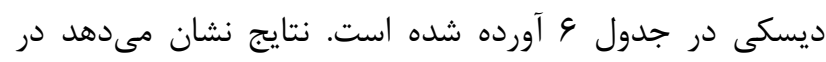

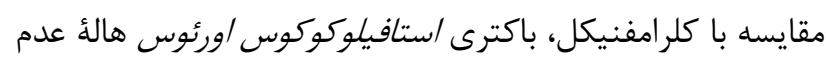

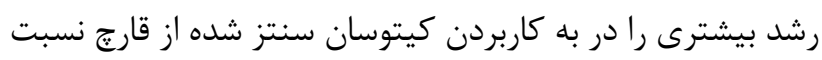
به /شرشيا كلى نشان مىدهد.
نشاندهندة فعاليت ضدباكتريايى آن است. براى كنترل مثبت اين

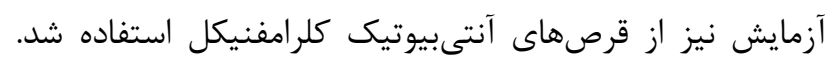

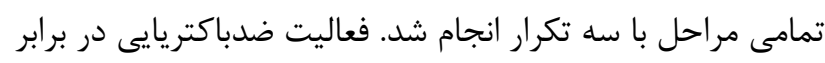

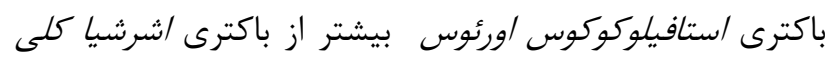

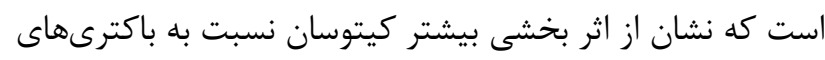

\begin{tabular}{|c|c|c|}
\hline استافيلوكوكوس /ورئوس & $r \pm 1 \Lambda$ \\
\hline اشرشيا كلى & $1 \pm 1 r$ & $r \pm r$ \\
\hline
\end{tabular}

خصوصيات فيزيكى كيتوسان قارجى را بر روى قارجهاى /بسيديا

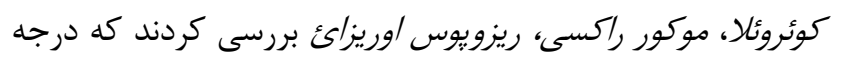

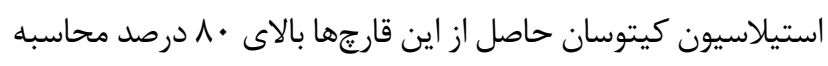

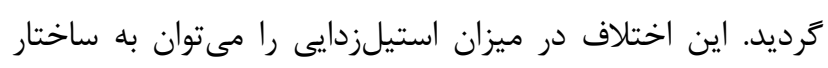

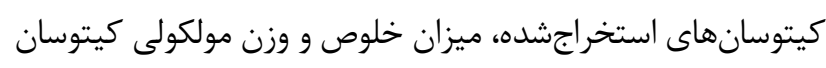

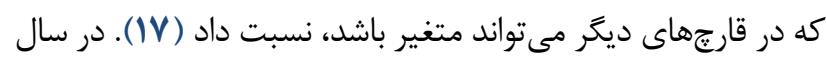

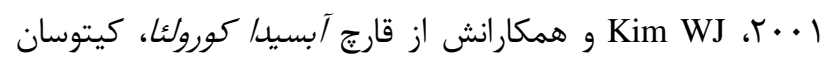

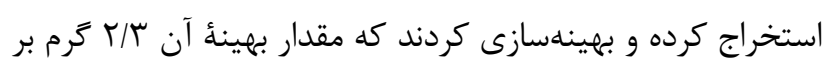

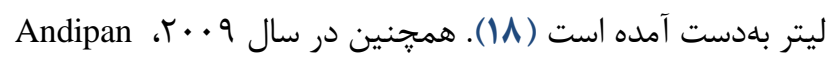

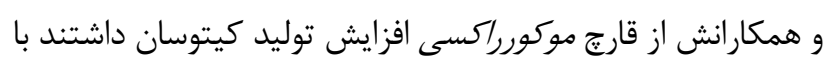

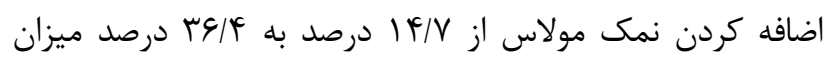

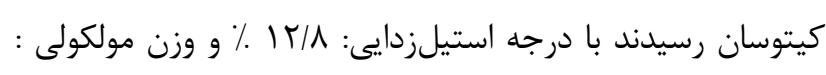

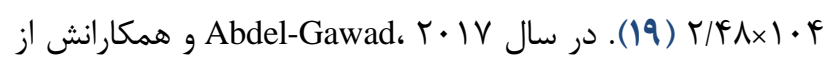

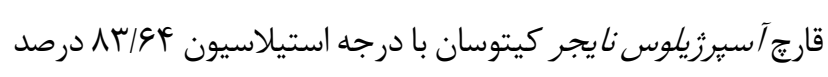

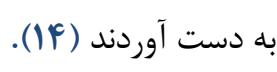
نتايج ميزان عدم رشد باكترى در آزمون انتشار ديسكى نشان

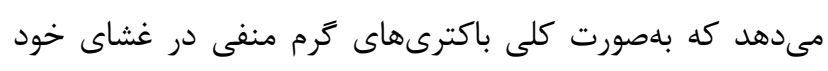

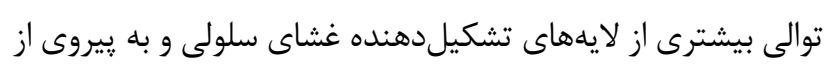

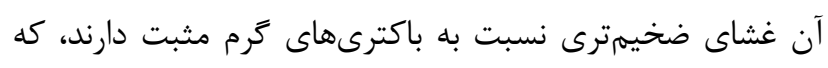

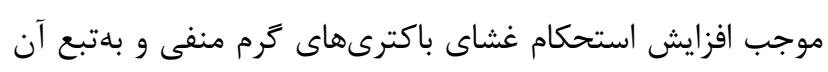
افزايش مقاومت آنها نسبت به مواد ضدباكتريايى شده است (IV) (IV).

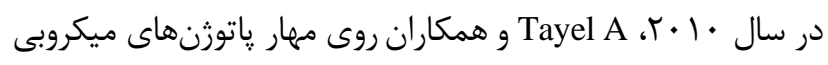
توسط كيتوسان قارجى كاركردند كه جهار نوع كيتوسان از قارئ

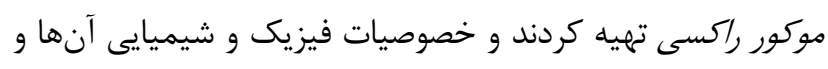

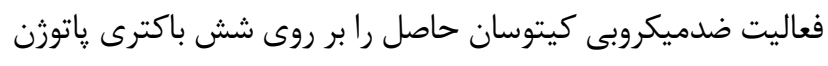

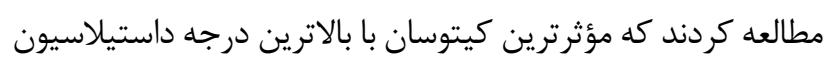

\section{بحث}

در اين يزوهش از قارج دارويى تراميتيس ورسيكالر بر اساس

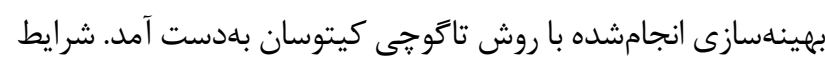

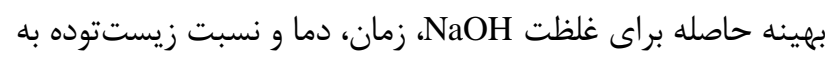

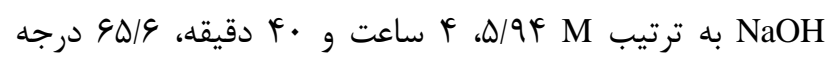

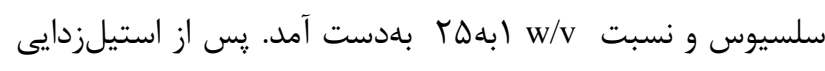

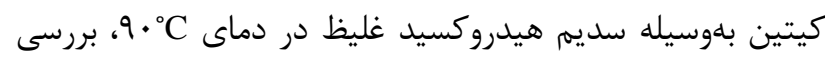

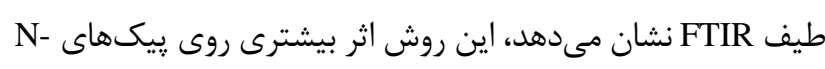
C-H, O-H ،H و مHCOCH استيل كيتين حذفشده و كيتوسان با گروههاى عاملى

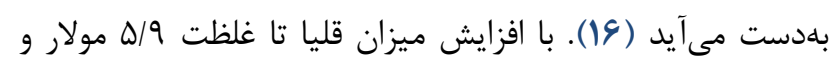

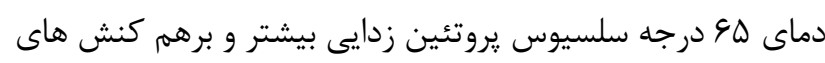
موثرترى بر روى ميسليوم و كيتين و درنهايت توليد بيشتر كيتوسان

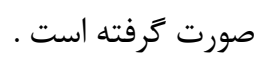

بر اساس يزوهشهاى انجام شده توسط برخى از محققين در

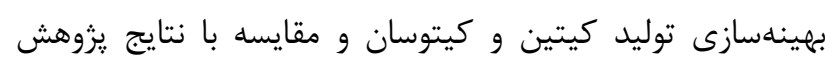

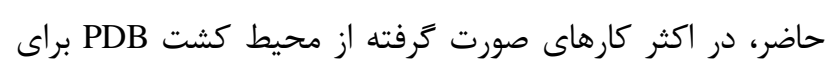

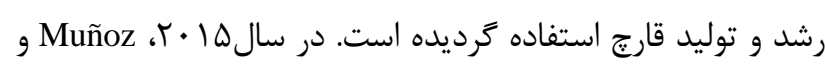

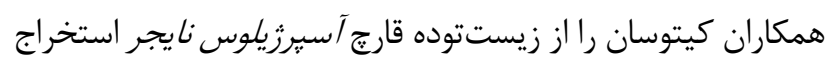

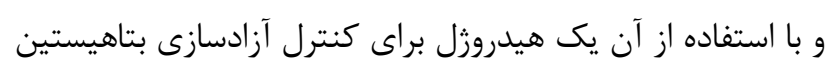

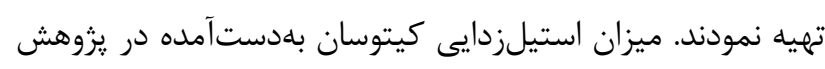

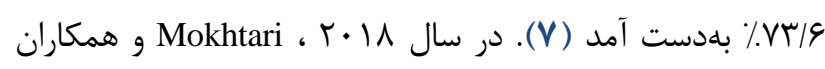

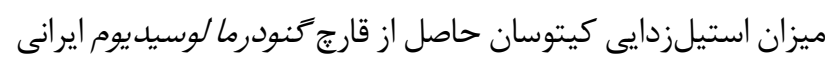

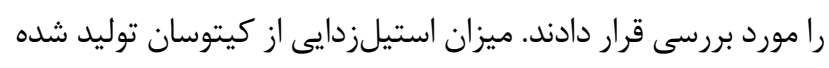

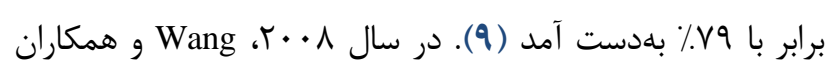


با درجه داستيلاسيون بالاتر بهترين جذب در سطح باكترىهاى گرم منفى و كرم مثبت را نشان داده pH پإيينتر جذب كيتوسان توسط دان

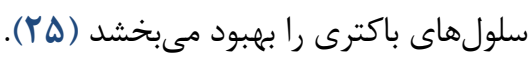

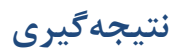

دراين يزوهش از قارج دارويى تراميتيس ورسيكالر بومى تائ

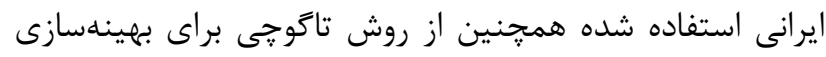

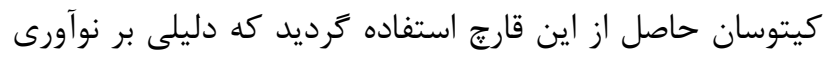
آن است. نتايج حاصل نشاندهنده درصد بالايى از شباهت آنائ

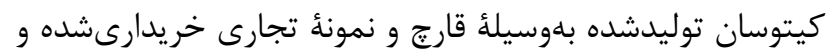

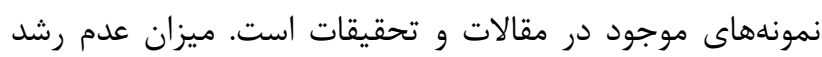
باكترى در برابر باكترىهاى/شرشيا كلى واستافيلوكوكوس /ورئوس

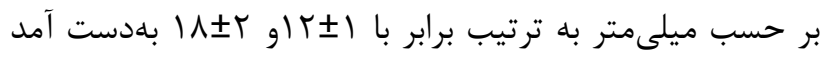

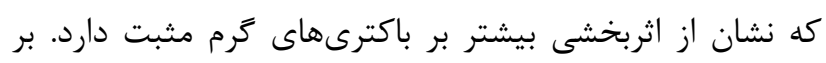
اساس بهينهسازى انجامشده براى افزايش ميزان استخراج كيتوسان

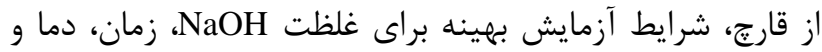

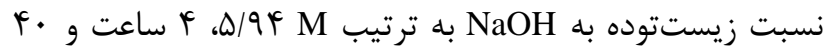

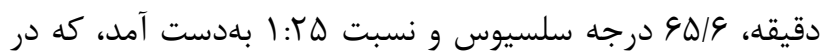

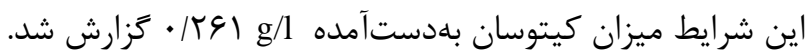

\section{سياسگزارى}

نتايج بهدست آمده حاصل از ياياننامه كارشناسى ارشد با كد

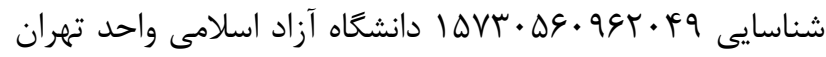
شمال است

$$
\text { تعارض در منافع }
$$

اين مقاله يزوهشى مستقل است و بدون حمايت مالى انجام شده است. در انجام مطالعه حاضر، نويسندگان هيجَّونه تضاد منافعى نداشتهاند.

\section{Referance}

1. Ribeiro B, Guedes de Pinho P, Andrade PB, Baptista P, Valentão P. Fatty acid composition of wild edible mushrooms species: A comparative study. Microchem J. 2009 Sep

1;93(1):29-35.

[DOI:10.1016/j.microc.2009.04.005]

2. Synytsya A, Míčková K, Synytsya A, Jablonský I, Spěváček J, Erban V, et al. Glucans from fruit bodies of cultivated mushrooms Pleurotus ostreatus and Pleurotus eryngii: Structure and potential prebiotic activity. Carbohydr Polym. 2009;76(4):548-56. [DOI:10.1016/j.carbpol.2008.11.021]
و كمترين ويسكوزيته و وزن مولكولى بود. بهطور كلى در شرايط رشد

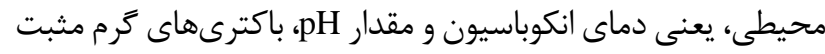
حساسيت بيشترى نسبت به عمل ضدميكروبى كيتوسان درمقايسه

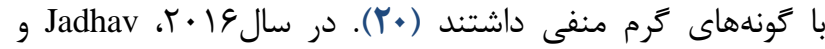
همكارش فعاليتهاى ضدميكروبى و خصوصيات فيزيكوشيميايى

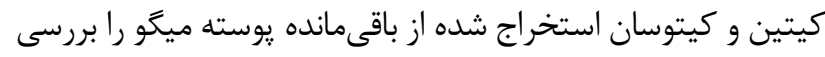

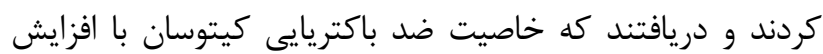

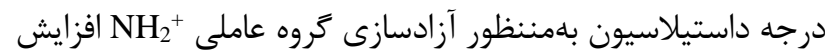

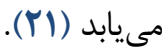

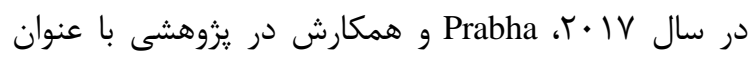
فعاليت ضد ميكروبى كيتوسان استخراج شده از يوستأ ميكو، قطر بان

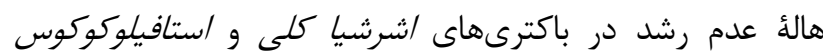

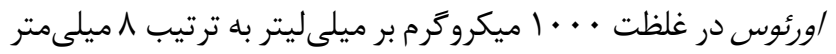
و • • ( ميلىمتر شد (rT). در سال \1 •r، Rakkhumkaew و همكارش خصوصيات ضدباكتريايى كيتوسان و كيتواليكوساكاريد حاصل از ضايعات يوسته

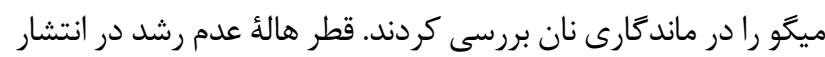

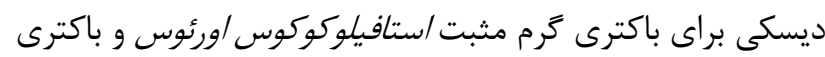

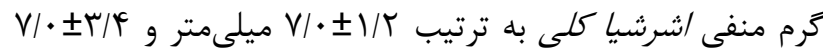

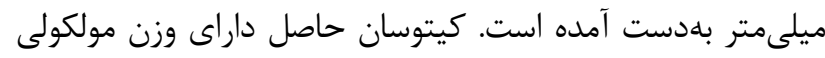

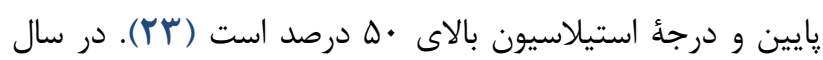
1 1 •r، Ahamed MIN و همكارانش در تحقيقى با عنوان توليد

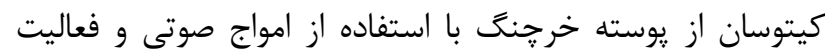

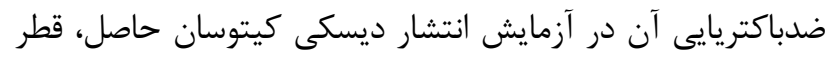

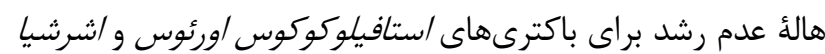

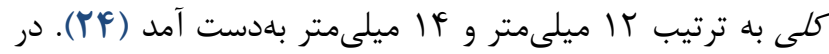
سال 9 • r، Kulawik و همكار انش طى يكى مقالة مرورى روى نقش كيتوسان روى غذاهاى دريايى تحقيق كردند و دريافتند كه كيتوسان

3. Ho CY, Lau CBS, Kim CF, Leung KN, Fung KP, Tse TF, et al. Differential effect of Coriolus versicolor ( Yunzhi ) extract on cytokine production by murine lymphocytes in vitro B. Int Immunopharmacol. 2004;4(12):1549-57. [DOI:10.1016/j.intimp.2004.07.021] [PMID]

4. Mengelizadeh N, HJ-S and, 2015 U. Physicochemical Characterization of Biopolymer Chitosan Extracted from Shrimp Shells. 19422511592.

5. Harish Prashanth KV, Tharanathan RN. Chitin/chitosan: modifications and their unlimited application potential-an overview. Trends Food Sci Technol. 2007 Mar 1;18(3):117-31. [DOI:10.1016/j.tifs.2006.10.022] 
6. Ravi Kumar MN. A review of chitin and chitosan applications. React Funct Polym. 2000 Nov 1;46(1):1-27. [DOI:10.1016/S1381-5148(00)00038-9]

7. Muñoz G, Valencia C, Valderruten N, Ruiz-Durántez E, Zuluaga F. Extraction of chitosan from Aspergillus niger mycelium and synthesis of hydrogels for controlled release of betahistine. React Funct Polym. 2015 Jun 1;9192:1-10. [DOI:10.1016/j.reactfunctpolym.2015.03.008]

8. Sathiyaseelan A, Shajahan A, Kalaichelvan PT, Kaviyarasan V. Fungal chitosan based nanocomposites sponges-An alternative medicine for wound dressing. Int J Biol Macromol. 2017 Nov 1;104:1905-15. [DOI:10.1016/j.ijbiomac.2017.03.188] [PMID]

9. Mokhtari-Hosseini Z-B, Hatamian-Zarmi A, Mohammadnejad J, Ebrahimi-Hosseinzadeh B. Chitin and chitosan biopolymer production from the Iranian medicinal fungus Ganoderma lucidum : Optimization and characterization. Prep Biochem Biotechnol. 2018 Aug 9;48(7):662-70. [DOI:10.1080/10826068.2018.1487847] [PMID]

10. Mesa Ospina N, Ospina Alvarez SP, Escobar Sierra DM, Rojas Vahos DF, Zapata Ocampo PA, Ossa Orozco CP. Isolation of chitosan from Ganoderma lucidum mushroom for biomedical applications. J Mater Sci Mater Med. 2015;26(3):1-9. [DOI:10.1007/s10856-015-5461-z] [PMID]

11. Ospina Álvarez SP, Ramírez Cadavid DA, Escobar Sierra DM, Ossa Orozco CP, Rojas Vahos DF, Zapata Ocampo $\mathrm{P}$, et al. Comparison of extraction methods of chitin from Ganoderma lucidum mushroom obtained in submerged culture. Biomed Res Int. 2014 Jan 15;2014:169071. [DOI:10.1155/2014/169071] [PMID] [PMCID]

12. Nitschke J, Altenbach H-J, Malolepszy T, Mölleken H. A new method for the quantification of chitin and chitosan in edible mushrooms. Carbohydr Res. 2011 Aug 16;346(11):1307-10. [DOI:10.1016/j.carres.2011.03.040] [PMID]

13. El-Hefian EA, Nasef MM, Yahaya AH. Preparation and Characterization of Chitosan/Poly(Vinyl Alcohol) Blended Films: Mechanical, Thermal and Surface Investigations. E-Journal Chem. 2011;8(1):91-6. [DOI:10.1155/2011/969062]

14. Abdel-Gawad KM, Hifney AF, Fawzy MA, Gomaa M. Technology optimization of chitosan production from Aspergillus niger biomass and its functional activities. Food Hydrocoll. 2017 Feb 1;63:593-601. [DOI:10.1016/j.foodhyd.2016.10.001]

15. Tajdini F, Amini MA, Nafissi-Varcheh N, Faramarzi MA. Production, physiochemical and antimicrobial properties of fungal chitosan from Rhizomucor miehei and Mucor racemosus. Int J Biol Macromol. 2010 Aug 1;47(2):180 3. [DOI:10.1016/j.ijbiomac.2010.05.002] [PMID]

16. Kumar HMPN, Prabhakar MN, Prasad CV, Rao KM, Kumar TVA, Rao KC, et al. Compatibility studies of chitosan / PVA blend in $2 \%$ aqueous acetic acid solution at $30 \circ$ C. Carbohydr Polym. 2010;82(2):251-5. [DOI:10.1016/j.carbpol.2010.04.021]
17. Wang W-P, Du Y-M, Wang X-Y. Physical properties of fungal chitosan. World J Microbiol Biotechnol. $2008 \mathrm{Nov}$ 17;24(11):2717-20. [DOI:10.1007/s11274-008-9755-x]

18. Kim WJ, Lee WG, Theodore K, Chang HN. Optimization of culture conditions and continuous production of chitosan by the fungi,Absidia coerulea. Biotechnol Bioprocess $\quad$ Eng. $2001 \quad$ Feb;6(1):6-10. [DOI:10.1007/BF02942243]

19. Andipan, Chatterjee S, Chatterjee BP, Guha AK. Influence of plant growth hormones on the growth of Mucor rouxii and chitosan production. Microbiol Res. 2009 Jan 1;164(3):347-51 [DOI:10.1016/j.micres.2007.05.003] [PMID]

20. Tayel AA, Moussa S, Opwis K, Knittel D, Schollmeyer E, Nickisch-Hartfiel A. Inhibition of microbial pathogens by fungal chitosan. Int J Biol Macromol. 2010 Jul;47(1):104. [DOI:10.1016/j.ijbiomac.2010.04.005] [PMID]

21. Jadhav AB, Diwan AD. Studies on antimicrobial activity and physicochemical properties of the chitin and chitosan isolated from shrimp shell waste. Indian J Geo-Marine Sci. 2018;47(3):674-80.

22. Prabha AR, Sivakumar K. Antimicrobial Activity of Chitosan Extracted from Prawn Shell. Indian J Appl Microbiol. 2017;20(1):1-7.

23. Rakkhumkaew N, Pengsuk C. Chitosan and chitooligosaccharides from shrimp shell waste: characterization, antimicrobial and shelf life extension in bread. Food Sci Biotechnol. 2018;27(4):1201-8. [DOI:10.1007/s10068-018-0332-2] [PMID] [PMCID]

24. Ahamed MIN, Gomathi N, Ragul V, Priya M, Priya R, Rumaan RS, et al. Novel Preparation of Chitosan from Crab Shell using Probe Sonicator and its Antibacterial activity. 2018;6(8):133-6.

25. Kulawik P, Jamróz E, Özogul F. Chitosan role for shelflife extension of seafood. Environ Chem Lett. 2019;(0123456789). [DOI:10.1007/s10311-019-009354] 